\title{
SPIRITUAL PRESENCE AND DiMENSIONAL SPACE BEYOND THE COSMOS
}

\author{
Hylarie Kochiras
}

Center for Philosophy of Science, 817 Cathedral of Learning, University of Pittsburgh, Pittsburgh, PA 15260 USA

Email:kochiras@pitt.edu

\begin{abstract}
This paper examines connections between concepts of space and extension on the one hand and immaterial spirits on the other, specifically the immanentist concept of spirits as present in rerum natura. Those holding an immanentist concept, such as Thomas Aquinas, typically understood spirits non-dimensionally as present by essence and power; and that concept was historically linked to holenmerism, the doctrine that the spirit is whole in every part. Yet as Aristotelian ideas about extension were challenged and an actual, infinite, dimensional space readmitted, a dimensionalist concept of spirit became possible - that asserted by the mature Henry More, as he repudiated holenmerism. Despite More's intentions, his dimensionalist concept opens the door to materialism, for supposing that spirits have parts outside parts implies that those parts could in principle be mapped onto the parts of divisible bodies. The specter of materialism broadens our interest in More's unconventional ideas, for the question of whether other early modern thinkers, including Isaac Newton, followed More becomes a question of whether they too unwittingly helped usher in materialism. This paper shows that More's attack upon holenmerism fails. He illegitimately injects his dimensionalist concept of spirit into the doctrine, failing to recognize it as a consequence of the non-dimensionalist concept of spirit, which in itself secures indivisibility. The interpretive consequence for Newton is that there is no prima facie reason to suppose that the charitable interpretation takes him to deny holenmerism.
\end{abstract}

Keywords: Divisibility, Henry More, Holenmerism, Nullibism, Space, Spirit, Thomas Aquinas, Void

\section{Introduction}

During the Renaissance, the concept of an actual, dimensional, infinite, and void space beyond the cosmos was readmitted. This space was no non-entity, existing only as a figment of the imagination. It was real. Nor was it a mere capacity to receive material bodies. Although it was incorporeal, it extended in three dimensions. And unlike the finite, intra-mundane vacua that had more easily gained acceptance, it extended infinitely. ${ }^{1}$ Finally, because the view that extension is an attribute of matter, and accordingly implies it, had lost its universal hold, this real, infinite, dimensional space extending beyond the material cosmos was void. Although this space resembled the spaces of the Greek atomists and the Epicureans in certain features, it may also be described as intuitive in its origin; for between ancient times and the Renaissance, it was a regular object of consideration, sometimes as a possibility for speculation, and often

\footnotetext{
${ }^{1}$ On the acceptance of finite vacua following the Condemnation of 1277, see Grant, Much Ado about Nothing, p. 116.
} 
as an impossibility to be denied. One reason to deny it was its potential to undermine the most comprehensive and fruitful natural philosophy then available, the Aristotelian system. Another reason was theological; if infinitude was a perfection, then to allow an actual infinite space was to admit a competitor to the infinite deity. ${ }^{2}$ Beliefs about God could thus constrain conceptions of space. Yet ideas about space could also influence conceptions of God. Readmitting an actual, dimensional void introduces an additional place for God's omnipresence to reach, for instance; and it also opens the possibility that God is literally present in space, because denying that extension must be corporeal breaks the conceptual link between extension and corruptibility. This paper traces the interplay between conceptions of space and extension on the one hand, and conceptions of immaterial spirits, both finite and divine, on the other.

Those who accept immaterial spirits cleave first over the question of whether those spirits, and the deity especially, are transcendent, existing apart from space and time, or immanent, being somehow present in rerum natura. It is the latter sort of view that will be my focus here, and when I speak of spirits, I mean those conceived as immanent, unless otherwise noted. Henry More (1614-1687) coined his own terms for these two conceptions, introducing the term nullibism to refer to the view that spirits are transcendent (from the Latin nullus, for 'nowhere'), and anti-nullibism for the opposing view that they are immanent. Instead of adopting his terminology, however, I will usually speak of spirits as either transcendent or immanent. ${ }^{3}$ Among those holding an immanentist conception of spirits, there is a good deal of spatial language. In a striking metaphor of medieval origin, God is described as "an infinite sphere whose center is everywhere and circumference nowhere", 4 and during the early modern period, immaterial spirits are sometimes described as being "diffused", “expanded”, or "extended". In describing the deity for instance, Joseph Raphson (1648-1715) asks rhetorically, "to be present by essence in places diverse and distant from one another, for instance in the globe of the Moon and in that of the earth, and also in the intermediate space, what else is it but, precisely, to extend oneself?"5 Yet such spatial language is rarely used to assert that spirits are dimensional, having the quantitative "parts outside parts" that could, at least in principle, be mapped onto the quantitative and divisible parts of bodies. With respect to the deity, this is in part because spatial descriptions were typically meant non-literally, at least

\footnotetext{
${ }^{2}$ Once Patrizi asserts an actual, infinite space, this theological concern begins to lose steam; Newton would counter it with the claim that infinitude is not in an of itself a perfection, for just as there can be infinity of a perfection, such as intellect, so too can there be infinity of imperfection, such as ignorance (see Newton, De gravitatione, p. 25 in Philosophical Writings; see also Newton's post-Principia manuscript, Tempus et Locus: "No thing is by eternity and infinity made better or of a more perfect nature, but only of longer duration in its own kind", trans. and discussed by McGuire, "Newton on Place, Time, and God: An Unpublished Source", p. 121). Still, the concern persists in some quarters; in Berkeley's Treatise we read, "Or else there is something besides God which is eternal, uncreated, infinite, indivisible, unmutable." Berkeley, A Treatise concerning the Principles of Human Knowledge, Part 1, in The Works of George Berkeley, ed. A. A. Luce and T. E. Jessop. (Edinburgh: Thomas Nelson and Sons, Ltd., 1949, 1I,94; in Power, p. 291.)

${ }^{3}$ One reason is that the term 'anti-nullibism' is a bit cumbersome. Another reason is that More sometimes imports his own assumptions along with his terminology, though I will not always avoid More's terminology on that ground.

${ }^{4}$ Grant, Much Ado about Nothing, p. 138, 139. Additional metaphors discussed by Grant include Saint Cyprian's remark that God is "one and diffused everywhere", and Boethius" claim that God is "everywhere but in no place" (see Grant, ibid., p. 113).

${ }^{5}$ Raphson, De spatio reali (1702) ch. 6, p. 82, trans. Koyre, (1957, pp. 197-198); in Grant, Much Ado about Nothing, p. 232.
} 
during the medieval period; such descriptions might convey the deity's grandeur while underscoring its inaccessibility to humans, and Thomas Aquinas (1225-1274) repeatedly emphasized that our limitations permit only analogical descriptions of God. An additional point, however - and one that applies to finite spirits as well as the deity-is that immanentist conceptions typically understood spirits as present by their essence and power. For a spirit to be spatially extended just is for its essence and power to be present, Raphson's remark providing an explicit statement of that view. Thus according to the prevailing conception, a spirit is non-dimensional, and the sense it which it is extended is derivative. Its extension derives from the presence of its essence and power in something that is intrinsically extended in the sense of having quantitative parts outside parts - be that matter, void, or both.

Although this non-dimensionalist sense of spiritual presence or extension remains dominant in the early modern period, and although he himself accepts that view in his early works, Henry More eventually reaches the highly unconventional conclusion that immaterial spirits are in fact dimensional. More does not go so far as to say that spirits are actually divisible, and hence corruptible; he attempts to retain their indivisibility by asserting their parts to be "indiscerpible" - incapable of being torn apart from one another and thereby actually divided. ${ }^{6}$ Yet his late writings do indicate the belief that spirits have the quantitative parts outside parts that could in principle be mapped onto the quantitative parts of bodies, which are divisible. ${ }^{7}$ One reason to consider More's concept of spirit is that it provides a window into the tandem changes of ideas about spirits and space; this dimensionalist concept simply was not possible for those insisting that extension is an attribute of matter, and became conceivable only by readmitting an incorporeal, dimensional space. But another reason for taking an interest in More's unusual view is that historically speaking, it becomes entwined with a doctrine intimately connected to the tenet that spirits are indivisible and hence incorruptible. This was the doctrine that the spirit is whole in every part or, according to the moniker that More provided by transliterating the Greek $o \lambda \varepsilon v \mu \varepsilon \rho \eta$, the doctrine of holenmerism. Thomas Hobbes (1588-1679) charged the doctrine with being incoherent; if the soul is entirely in a man's little finger, he jeered, there can be nothing left to occupy any other place in his body. Although More initially embraced the doctrine, along with the prevailing view of spirits, he later repudiated it by arguments echoing Hobbes' charge. More left his stamp upon the doctrine, and in doing so he perhaps unwittingly helped open the door to materialism. The consequences of assessing More's arguments therefore extend beyond his own thought, into interpretive questions about other early modern figures anxious to oppose materialism, including Isaac Newton (1642-1727).

\footnotetext{
${ }^{6}$ More explains the term as follows: "By Actual Divisibility I understand Discerpibility, gross tearing or cutting of one part from the other." (Henry More, The Immortality of the Soul, Book I, chapter II, Axiom IX, p. 63 in MacKinnon.)

${ }^{7}$ Here I concur with Reid's observation that according to the view that More eventually embraces, "it does indeed appear that the only remaining possibility must be that one part of his soul should be present in his head while a different part is present in his toe.”(Reid, “The Evolution of Henry More's Theory of Divine Absolute Space”, p. 100)
} 
As I will show, the doctrine of holenmerism appears incoherent only because when More repudiates it, he misrepresents it in two related ways. First, he illegitimately imports into it his own dimensionalist conception of spirits. Second, because he presumes that dimensionalist conception, he further presumes that holenmerism is to its proponents nothing but an ad hoc stipulation designed to block the divisibility that a dimensionalist conception of spirits threatens. Yet as we will see, the doctrine that the spirit is whole in every part was traditionally associated with the non-dimensionalist conception that takes spirits to be present by essence and power, not by having parts outside parts. Further, it was neither intended nor needed as a means to secure the indivisibility of spirits. Although More's presumption that holenmerism was intended to ground the indivisibility of spirits is sometimes recounted without challenge, ${ }^{8}$ we shall see that in fact the indivisibility of spirits simply follows, together with their being whole in every part, as a consequence of the prevailing, non-dimensionalist conception of spirits as present by essence and power. The charge that holenmerism is an incoherent doctrine therefore fails, which means there is no prima facie reason to reject the doctrine. For an early modern thinker such as Newton, one must of course ask whether his ontology could accommodate a doctrine whose fullest development was given by Aristotelians such as Aquinas, but the conclusions reached here imply that a charitable interpretation of Newton need not suppose that he rejected holenmerism. The next section examines the doctrine of holenmerism, primarily as articulated by Aquinas, in connection with his non-dimensionalist concept of spirits. The third section considers changing ideas about space and extension generally as an infinite dimensional void is reintroduced. The fourth section focuses upon More's ideas about spirits and spiritual presence, and argues for the conclusions just noted. After a brief review of results, the concluding section suggests some applications to Newton's thought.

\section{Spiritual presence through essence and power and the doctrine of holenmerism}

\subsection{Early formulations of holenmerism and the distinction between ubi circumscriptivum and ubi definitivum}

The doctrine that the spirit is both whole in the whole and whole in every part-holenmerism, as I shall continue to call it, anachronistically_originated with Plotinus (c. 207-270) in Enneads IV.2.1, whose formulation of it concerned the relationship of the soul to the body. Although the soul was divisible in virtue of "its presence at every point of the recipient", Plotinus wrote, it was yet indivisible in

\footnotetext{
${ }^{8}$ See, for instance, Reid, ibid., p. 100: “And the whole holenmerian approach was wrong-headed anyway, he [More] suggested, for it had been constructed specifically in order to avoid the problem of rendering spirits susceptible to division into several parts, which was apparently going to arise if extension in the "parts outside parts" sense was ascribed to them." See also Slowik, "Newton’s Neo-Platonic Ontology of Space"; in $\S 4.2$, he describes holenmerism as "a belief common among the Scholastics, that God is whole in every part of space (which thereby guarantees that God is not divisible even if matter and space were divisible; More 1995, 98-148)."
} 
virtue of "dwelling entire in the total and entire in any part" of the body. ${ }^{9}$ Christian thinkers then extended the doctrine to God and angels, and in works drawing upon St. Augustine (354-430), both St. John Damascene (c. 675-749) and Peter Lombard (c. 1095-1160) were influential in disseminating it. ${ }^{10}$

The question of how spirits, as opposed to bodies, are located in places was addressed by Peter Lombard, who introduced two conceptions that would, once subsequent thinkers had modified his terms, come to be known by the labels ubi circumscriptivum and ubi definitivum. Ubi circumscriptivum referred to the filling of a place, and applied to bodies alone; a body fills, occupies, or is co-extensive with its place. Ubi definitivum referred to being in a place in the sense of being locatable via the terminus or boundary of a place, and was considered to apply both to bodies and to spirits, albeit only finite spirits. It applied to bodies in that a body, which fills a place, is also locatable by the boundary of the place that delimits it. ${ }^{11}$ It applied to finite spirits, to wit, souls and angels, in that such a spirit is locatable, even though it does not fill place, because it is delimited by the place's terminus. Neither concept applied to the infinite deity. Being non-corporeal, God does not have ubi circumscriptivum, but being an infinite being, without limit, neither does he have ubi definitivum. In general, the deity's relation to place was treated as a question distinct from, if related to, the relations of finite spirits to place.

Since the notion of ubi definitivum refers to a manner of being present without filling place, the spirits to which it applies are clearly conceived as non-dimensional. Ubi definitivum also came to connote the view that the finite spirit was whole in every part of its place, ${ }^{12}$ linking the non-dimensionalist concept of spirit to holenmerism.

\subsection{Aquinas on spiritual presence and indivisibility}

In Aquinas we find the doctrine of holenmerism, along with a non-dimensionalist concept of spirit. Aquinas' use of spatial language might initially belie that conception; he writes of God existing in things and everywhere, and he reaffirms passages of Scripture employing spatial language, including Jeremiah 23:24, "I fill heaven and earth". Yet we are to understand such spatial language analogically when it is applied to the deity, as our limitations leave us short of any literal understanding. ${ }^{13}$ Moreover, Aquinas

\footnotetext{
${ }^{9}$ Plotinus, Enneads IV .2.1, translated by Stephen MacKenna; in Grant, Much Ado about Nothing, p. 350, n. 127.)

${ }^{10}$ See Grant, Much Ado about Nothing, p. 350, n. 127.

${ }^{11}$ See Grant, Much Ado about Nothing, p. 342.

12 See Grant, Much Ado about Nothing, p. 343: "The ubi definitivum also came to be characterized by the assumption that a spiritual substance could fill not only the whole of the place that delimited it but the whole of that spiritual substance, for example, an angel or soul, was in every part of its place or ubi definitivum."(Grant, Much Ado, p. 343, note 67. ) Grant also points out that Peter Lombard seems to have crafted his concepts without attempting to explain the relevant sense of 'place', which is to say without either affirming the Aristotelian notion of place as a two-dimensional boundary or containing surface, or repudiating it in favor of the concept of an incorporeal extension that is distinct from any entity that might occupy it; see Grant, ibid., p. 242.

${ }^{13}$ Aquinas held, with Averroes and neo-Platonist predecessors, that the language by which we describe God is equivocal; it cannot have the same meaning as it has when applied to the finite things of God's creation. On this point, see Funkenstein, Theology and the Scientific Imagination from the Middle Ages to the Seventeenth Century, pp. 50-54.
} 
could hardly conceive of any spirit as being dimensional, given his ideas about extension. Although he speculates about the possibility of void space, for the most part he takes extension to be an attribute of matter, and since on that view it implies corporeality, extension could not be an intrinsic feature of immaterial spirit. Spirits can be extended, then, only in the derivative sense of being present in things that are extended in three dimensions, which is to say bodies, ${ }^{14}$ and Aquinas tends to speak in terms of things being in a place.

For Aquinas, the manner in which anything is in a place must reflect its position on the scale of being. Although being is ultimately divinely conferred, form or essence, as a principle of actuality, plays a role, and so substances differ in nature and position on the scale of being according to their forms or essences and the relative degrees of potentiality and actuality which they possess. The more potentiality a substance has, the farther down the scale it is, while the more actuality it has, the farther up the scale it is, with those substances whose form or essence implies being occupying a very high position. Material substances are low on the scale, since their forms require perishable matter, a principle of potentiality, in order to be instantiated. Human beings are higher on the scale in virtue of having immortal souls. A purely incorporeal being is higher still because it is free of matter, and indeed its form or essence implies its being, though its actual being must still be given by the deity. God, occupying the apex of the scale, is pure actuality, the one whose essence does not imply his being but is rather identical to it. ${ }^{15}$

The way that God and other immaterial spirits are in things and places is categorically different from the way that material bodies are in places. In the course of addressing the question of whether God is everywhere, Aquinas provides a general statement of that difference: "Incorporeal things are in place not by contact of dimensive quantity, as bodies are but by contact of power." ${ }^{\prime 6}$ This is true of angels, and all the more true of God. As a finite being, an angel is present is some finite place. It is present there virtually (per contactum virtutis), that is to say, through its angelic power. ${ }^{17}$ And while two angels cannot simultaneously occupy the same place, the reason for this is not that they exclude one another via dimensive quantity, as bodies do, for angels have no dimensive quantity. The reason is rather one that follows from their manner of being in places by power: "it is impossible for two complete causes to be the causes immediately of one and the same thing." 18 The infinite deity, by contrast, is present everywhere.

\footnotetext{
${ }^{14}$ Aquinas himself does not put things in those terms, and indeed, the need to do so arises only with the possibility of alternative conceptions of space and extension.

${ }^{15}$ Funkenstein, Theology and the Scientific Imagination from the Middle Ages to the Seventeenth Century, p. 51

${ }^{16}$ Aquinas, Summa Theologiae I Q.8. Art.2; Reply to Obj. 1. See also the rest of article 2, and Q.52. Art.1.

17 "A body is said to be in a place in such a way that it is applied to such place according to the contact of dimensive quantity; but there is no such quantity in the angels, for theirs is a virtual one. Consequently an angel is said to be in a corporeal place by application of the angelic power in any manner whatever to any place.”(Aquinas, ST I Q.52.Art.1)

18 "There are not two angels in the same place. The reason of this is because it is impossible for two complete causes to be the causes immediately of one and the same thing. This is evident in every class of causes: for there is one proximate form of one thing, and there is one proximate mover, although there may be several remote movers. Nor can it be objected that several individuals may row a boat, since no one of them is a perfect mover, because no one man's strength is sufficient for moving the
} 
The way that bodies fill place provides a strong contrast to the way that that the deity fills it. Whereas bodies exclude one another, God does not exclude anything, but rather fills every place "by the very fact that he gives being to the things that fill every place." 19 Place itself is given being by God: "As He is in all things giving them being, power and operation; so $\mathrm{He}$ is in every place as giving it existence and locative power.",20

That spirits are present by power, as opposed to parts outside parts, is especially evident once we realize that where spirits are concerned, Aquinas construes the notion of action at a distance in terms of causal power. In affirmatively answering the question of whether God is in all things, Aquinas refers both to the principle that an agent must be present to that upon which it acts, and to Aristotle's claim in Physics vii that a thing that is moved must be joined to its mover. He elaborates as follows: "Since God is very being by His own essence, created being must be His proper effect; as to ignite is the proper effect of fire...[and] God causes this effect in things not only when they first begin to be, but as long as they are preserved in being..... as long as a thing has being, God must be present to it." ${ }^{21}$ Then, in rebutting the objection that God need not be in all things, since the greater a power, the farther its reach, Aquinas writes, "No action of an agent, however powerful it may be, acts at a distance, except through a medium. But it belongs to the great power of God that He acts immediately in all things. Hence nothing is distant from Him, as if it could be without God in itself." 22 This last sentence serves as a reminder that spatial terms are intended analogically when applied to the deity. To say that one body is distant from another is to say that the limiting edge of one body's dimensive parts does not abut the limiting edge of the other's dimensive parts; but to say that God was distant from something would be to suppose the impossible, namely, that that thing could exist without his causal and sustaining power.

According to the complex analysis that Aquinas provides, God is in things in both agent and object senses, ${ }^{23}$ but it is the former that is most pertinent here. This agent sense of presence concerns God's

boat; while all together are as one mover, in so far as their united strengths all combine in producing the one movement. Hence, since the angel is said to be in one place by the fact that his power touches the place immediately by way of a perfect container, as was said...there can be but one angel in one place." (Aquinas, ST I Q.52. Art.3)

${ }^{19}$ Aquinas, ST I Q.8.Art.2: "God fills every place; not, indeed, like a body, for a body is said to fill place inasmuch as it excludes the co-presence of another body; whereas by God being in a place, others are not thereby excluded from it; indeed, by the very fact that He gives being to the things that fill every place, He Himself fills every place."

${ }^{20}$ Aquinas, ST I Q.8.Art.2.

${ }^{21}$ Aquinas, ST I Q.8.Art.1.

${ }^{22}$ Aquinas, ST I Q.8.Art.1. The claim will be reiterated by Suarez and More, among others.

${ }^{23}$ Thus one sense in which God is in things is as "an object of operation is in the operator". Most especially, God is in the rational beings who know and love him, as the object of their knowledge and love. (See Aquinas, ST, I.Q.8 Art.3: God is said to be in a thing in two ways; in one way after the manner of an efficient cause; and thus He is in all things created by Him; in another way he is in things as the object of operation is in the operator; and this is proper to the operations of the soul, according as the thing known is in the one who knows; and the thing desired in the one desiring. In this second way God is especially in the rational creature which knows and loves Him actually or habitually.) God's being in things is consistent with their being also in God, and as Aquinas clarifies elsewhere in the same article, things are, with respect to knowledge and will, "more truly in God than God in things". (ST, I.Q.8 Art.3, reply to obj. 3.) 
capacities as the agent of infinite power, the efficient cause ${ }^{24}$ who provides being to all things. This agent sense subdivides, as ubiquity by presence, by power, and by essence. God is in all things by presence: "He is by His presence in all things, as all things are bare and open to His eyes". ${ }^{25}$ This is an epistemological aspect of God's agency, and finding an analogy for it in human affairs, Aquinas observes that things in a house can be subject to the inspection of someone who is not, in substance, in every part of the house. ${ }^{26}$ God is further in all things by power: "God is in all things by His power, inasmuch as all things are subject to His power." 27 Here Aquinas means to contest the Manichean position that God's power is limited, extending not to material things but only to spiritual ones, and here again Aquinas finds an analogy in human affairs: "A king...is said to be in the whole kingdom by his power, although he is not everywhere present." ${ }^{28}$ Finally, God is in all things by essence - by the presence of his substance ${ }^{29}$ which is the cause of all being: "He is in all things by His essence, inasmuch as $\mathrm{He}$ is present to all as the cause of their being." ${ }^{30}$ Part of the point here is to emphasize the dependence of secondary causes upon God; while a father in one sense produces his children, God is the ultimate cause of all being. ${ }^{31}$

In the course of addressing questions of whether God is everywhere, and whether being everywhere belongs to God alone, ${ }^{32}$ Aquinas asserts a holenmerist thesis, one expressing his conception of spirits as non-dimensional. Immaterial spirits are in things that have parts, yet unlike bodies, which are in places by dimensional parts and are thus divisible, spirits are indivisible, being whole in every part: "As the soul is whole in every part of the body, so is God whole in all things and in each one." ${ }^{33}$ In explaining how this is possible, Aquinas counters objections that rely upon such assumptions as that the only totality is a quantitative totality, and that the only indivisible is one belonging to a continuum.

According to one of the objections, then, that which is wholly in one place cannot be elsewhere; and since God has no parts, if he is in one place, he cannot be elsewhere, and thus is not omnipresent. ${ }^{34}$ Aquinas' reply depends upon countering the assumption that there is no other kind of totality or part than a quantifiable kind. It is true that we call something whole in reference to its parts. And it is true that one kind of parts are parts of quantity, the parts into which any quantity may be divided, such that the whole

${ }^{24}$ Aquinas, ST, I.Q.8 Art.3.

${ }^{25}$ Aquinas, ST I Q.8.Art.4

${ }^{26}$ Aquinas, ST I Q.8.Art.3. "A thing is said to be by its presence in other things which are subject to its inspection; as things in a house are said to be present to anyone, who nevertheless may not be in substance in every part of the house."

${ }^{27}$ Aquinas, ST I Q.8.Art.4.

${ }^{28}$ Aquinas, ST, I.Q.8 Art.3.

${ }^{29}$ Aquinas, ST, I.Q.8 Art.3, Reply to Obj. 1: "God is said to be in all things...by His own essence; because His substance is present to all things as the cause of their being."

${ }^{30}$ Aquinas, ST I Q.8.Art.4.

31 "Further, others said that, although all things are subject to God's providence, still all things are not immediately created by God; but that He immediately created the first creatures, and these created the others. Against these it is necessary to say that He is in all things by His essence." (Aquinas, ST I Q.8 Art.3.)

${ }^{32}$ Aquinas, Articles 2 and 4 of Question 8, respectively.

${ }^{33}$ Aquinas, ST I Q.8.Art.2; Reply to Obj.3.

34 "Objection 3: Further, what is wholly in any one place is not in part elsewhere. But if God is in any one place He is all there; for He has no parts. No part of Him then is elsewhere; and therefore God is not everywhere." Aquinas, ST I Q.8.Art.2 
quantifiable thing is commensurate with its whole place, and each part of the thing commensurate with only a part of that whole place, such that the whole cannot be in a mere part. ${ }^{35}$ Yet there are also parts of another kind, parts that are not quantifiable. These are parts of essence. Form and matter, for instance, are parts of a composite, and so "the intellect by which Socrates understands is a part of Socrates, so that in some way it is united to the body of Socrates". ${ }^{36}$ Similarly, genus and difference are parts of a species. ${ }^{37}$ A genus without difference is not a species, thus difference is part of the species. Yet we cannot divide the difference into half, or otherwise consider it quantitatively with respect to the species. Now, "totality of essence is not commensurate to totality of place". ${ }^{38}$ And while accidental forms may have accidental quantity, immaterial spirits do not have quantity in any manner whatsoever, "except in reference to the perfect idea of their essence"; and so God is whole in all things and in their parts, just as the soul is whole in every part of the body. ${ }^{39}$

In rebutting another objection, Aquinas directly associates the holenmerist thesis that a spirit is whole in every part with the non-dimensionalist conception of spiritual presence by power. According to the objection, just as an indivisible part of a movement cannot exist in different times, so an indivisible part of a permanent thing cannot be in all places; and since the deity is permanent, he is not in many places, and is not omnipresent. In responding, Aquinas argues that the objection acknowledges only one of two sorts of indivisibles, namely, an indivisible in a continuum. A point is an indivisible in a permanent continuum; and as it has a determinate site, the objection is correct in holding that it cannot be in many places or parts of places. A moment in a movement is an indivisible in an impermanent continuum, a succession; and as it has a determinate order in that movement, it cannot be in many parts of time. Yet the objection overlooks another sort of indivisible, one that does not belong to a continuum but instead involves touching a place by its power. It is in this manner that God, angels, and souls are in things and yet indivisible, such that the soul is whole in the body, and God whole in the parts of every

\footnotetext{
35 "What therefore is whole in any place by totality of quantity, cannot be outside of that place, because the quantity of anything placed is commensurate to the quantity of the place; and hence there is no totality of quantity without totality of place." (Aquinas, ST I Q.8.Art.2; Reply to Obj.3)

${ }^{36}$ Aquinas, ST I Q.76.Art.1.

${ }^{37}$ Aquinas, ST I Q.8.Art.2; Reply to Obj.3.

${ }^{38}$ Aquinas, ST I Q.8.Art.2; Reply to Obj.3.

${ }^{39}$ Aquinas clarifies that that accidental forms - properties such as whiteness - have accidental quantity. If we consider whiteness in terms of its essence, it is whole in every part of a white surface, "because according to the perfect idea of its species it is found to exist in every part of the surface". (Q.8.Art.2; Reply to Obj.3) But the quantity that it has accidentally, in virtue of the surface being large or small, may also be considered; and in terms of this accidental quantity, it is not whole in every part of the surface. But incorporeal substances do not have quantity in even this accidental way, Aquinas emphasizes. After allowing accidental quantity to accidental forms, he writes, "On the other hand, incorporeal substances have no totality either of themselves or accidentally, except in reference to the perfect idea of their essence. Hence, as the soul is whole in every part of the body, so is God whole in all things and in each one." (Aquinas, ST I Q.8.Art.2; Reply to Obj.3)
} 
thing and place. ${ }^{40}$ (And of course, only God is everywhere, as Aquinas argues in article 4, assuming along the way the Aristotelian conception of place. ${ }^{41}$ )

When Aquinas turns his attention to the rational soul in particular, he reiterates both the nondimensionalist conception of that soul and the holenmerist thesis, elaborating certain points. There is only one, incorruptible soul in the rational human, because the intellectual, sensitive, and nutritive souls are numerically one. ${ }^{42}$ The soul and body together are a composite, a complete substance, the human being; the intellect is a part of the human being, but the body is also a part of the human being, the body being required for sensation. ${ }^{43}$ Further, it is by the intellect that the body acts, and so the intellect is the substantial form of the body. ${ }^{44}$ Unlike an accidental form — such as the form of a house, which is a structure external to the stone or wood of the house - a substantial form internally structures the substance to which it belongs, conferring attributes and powers upon it, including, for animate beings, powers of action. As the substantial form of the body, the soul is, as Augustine wrote, ${ }^{45}$ whole in every part of the body. In the following paragraph, Aquinas affirms that thesis together with its ground and the confirming observation that no part of the body is able to act once its union with the soul is broken by death.

Since the soul is united to the body as its form, it must necessarily be in the whole body, and in each part thereof. For it is not an accidental form, but the substantial form of the body. Now the substantial form perfects not only the whole, but each part of the whole. For since a whole consists of parts, a form of the whole which does not give existence to each of the parts of the body, is a form consisting in composition and order, such as the form of a house; and such a form is accidental. But the soul is a substantial form; and therefore it must be the form and the act, not only of the whole, but also of each part. Therefore, on the withdrawal of the soul...we do not speak of an animal or a man unless equivocally, as we speak of.... stone animal; so is it with the hand, the eye, the flesh and bones, as the Philosopher says (De Anima ii, 1). A proof of which is, that on the withdrawal of the soul, no part of the body retains its proper action.....act is in that which it actuates: wherefore the soul must be in the whole body, and in each part thereof. ${ }^{46}$

\footnotetext{
${ }^{40}$ Aquinas, ST I Q.8.Art.2; Reply to Obj. 2. I have closely paraphrased certain parts of Aquinas' reply (as translated by Fathers of the English Dominican Province), which reads as follows. "Reply to Objection 2: The indivisible is twofold. One is the term of the continuous; as a point in permanent things, and as a moment in succession; and this kind of the indivisible in permanent things, forasmuch as it has a determinate site, cannot be in many parts of place, or in many places; likewise the indivisible of action or movement, forasmuch as it has a determinate order in movement or action, cannot be in many parts of time. Another kind of the indivisible is outside of the whole genus of the continuous; and in this way incorporeal substances, like God, angel and soul, are called indivisible. Such a kind of indivisible does not belong to the continuous, as a part of it, but as touching it by its power; hence, according as its power can extend itself to one or to many, to a small thing, or to a great one, in this way it is in one or in many places, and in a small or large place."

${ }^{41}$ In Article 4, Aquinas argues that it is proper to God to be everywhere absolutely, which is to say, on any conditions that might be supposed. He contrasts this to the case on which a thing, say a millet seed, could be everywhere only given a particular supposition - that no other body existed, and in so doing evinces the Aristotelian notion that there is no place beyond existent bodies.

${ }^{42}$ Aquinas, ST I Q.76.Art. 3.

43 "One cannot sense without a body: therefore the body must be some part of man. It follows therefore that the intellect by which Socrates understands is a part of Socrates, so that in some way it is united to the body of Socrates."(ST I Q.76.Art.1)

44 "The intellect which is the principle of intellectual operation is the form of the human body. For that whereby primarily anything acts is a form of the thing to which the act is to be attributed."(ST I Q.76.Art.1)

45 "In each body the whole soul is in the whole body, and in each part is entire", Augustine of Hippo, De Trin. vi, 6, quoted by Aquinas at ST I Q.76.Art.8.

${ }^{46}$ Aquinas, ST I Q.76.Art.8.
} 
To suppose that the soul could not be wholly present in every part of the body is to suppose mistakenly that all parts and wholes are of a quantifiable sort, as Aquinas explained earlier in considering God's presence. The first sort of whole or totality is indeed that of quantity. But while bodies and lines are quantifiable wholes, which may be divided into parts of quantity, a soul cannot be divided into such parts. A second sort of whole (noted earlier in connection with the discussion of God's presence) is that having logical and essential parts. Here Aquinas provides the example of a thing defined, which is "divided into the parts of a definition", ${ }^{47}$ while reiterating the aforementioned example of a composite divided into matter and form. The third kind of whole, which Aquinas refers to as "potential, divided into virtual parts", ${ }^{48}$ concerns powers. The intellectual soul is a totality in the second and third senses, but not in the first sense (not even accidentally, as is the case with some forms.)

Since the soul is not a totality of quantity, the question of whether its quantity is whole in the parts of the body simply does not apply. That the soul cannot be divided into parts of quantity is not due to its being a form, but is instead due to the kind of form that it is, for there are some forms that can be divided into parts of quantity, though only accidentally. These are forms having "an indifferent relationship to a quantitative whole and its parts", ${ }^{49}$ and because of that indifferent relationship, it is only accidentally that such forms can be divided into quantitative parts. Thus, a form such as whiteness has an indifferent relationship to a quantitative whole, which is to say that it does not produce any characteristic variety of properties in different parts of the body to which it belongs, and since it is equally disposed to be in every part of a white surface, it is accidentally divided if the surface is divided. A soul, by contrast, does produce and require variety in the parts, such that the body to which it belongs will have legs for walking and eyes for seeing. If the body to which the soul is joined is divided in some manner, by the amputation of an arm or leg for instance, the soul is not divided into quantitative parts, even accidentally. ${ }^{50}$ This is evident because the soul confers actuating powers upon the body, and an amputated limb retains no power of motion, the soul having remained entire in the rest of the body. Since the soul does not have quantity even accidentally, then, to say that the soul is whole in every part of the body is not to assert that one quantity is simultaneously commensurate both to another quantity and to some proper part of it.

The intellectual soul does have totality of essence, however, and totality of potential or powers, so one can sensibly ask whether it is whole in every part of the body in either or both of these senses. But

\footnotetext{
${ }^{47}$ Aquinas, ST I Q.76.Art.8.

${ }^{48}$ Aquinas, ST I Q.76.Art.8.

${ }^{49}$ Aquinas, ST I Q.76.Art.8

50 "The first kind of totality does not apply to forms, except perhaps accidentally; and then only to those forms, which have an indifferent relationship to a quantitative whole and its parts; as whiteness, as far as its essence is concerned, is equally disposed to be in the whole surface and in each part of the surface; and, therefore, the surface being divided, the whiteness is accidentally divided. But a form which requires variety in the parts, such as a soul, and specially the soul of perfect animals, is not equally related to the whole and the parts: hence it is not divided accidentally when the whole is divided. So therefore quantitative totality cannot be attributed to the soul, either essentially or accidentally." (Aquinas, ST I Q.76.Art.8)
} 
while one can sensibly raise the question for both senses, the soul is whole in every part of the body in only one of those two senses. The soul is not whole by power in every part of the body. For one thing, certain powers require certain parts of the body and are specific to them, notably, the power of sight is in the eye, and the power of hearing in the ear. ${ }^{51}$ For another thing, the intellect is not localized in any part of the body, and by power the intellect is not in the body at all ${ }^{52}$ (a claim that Descartes will affirm by reconfiguring souls as all and only rational, and as complete substances). The soul is whole in every part of the body by essence - "by totality of perfection and of essence". For again, the soul is not an accidental form, but a substantial one, which confers properties and the power of action.

Although these Thomistic doctrines would find detractors - with John Duns Scotus (1265-1308) and William of Ockham (1285-1347), for instance, asserting a transcendent God who need not be substantially present to that upon which he acts - they were highly influential, and would be reaffirmed in an elaborate analysis by Francisco Suarez (1548-1617). The intellectual soul, Suarez agrees, cannot be divided. ${ }^{53}$ If a person undergoes the amputation of a limb, the rational soul remains in the person's body, and so no part of the will or power of movement will be taken away with the arm. ${ }^{54}$ (By contrast, both parts of a plant cut in two may live and grow, and both parts of a worm, once divided, may live and retain the power of movement, because souls that are merely vegetative or sensitive are divisible. ${ }^{55}$ ) Suarez also adheres closely to Aquinas' conception of the deity, asserting God's immanence through the presence of essence and power, the indivisibility of the deity, and the doctrine of holenmerism. Citing his predecessor, Suarez writes, "From God's universal influx and action it follows that God is everywhere really and intimately present in all things. ${ }^{~} 56$ He again follows Aquinas in grounding the claim that God is immanent. "Every agent must be joined to the patient on which the agent acts," ${ }^{, 57}$ Suarez holds, and argues that this principle is fully general, not being restricted to finite substances, as some have held, but

\footnotetext{
51 "The whole soul is in each part of the body, by totality of perfection and of essence, but not by totality of power. For it is not in each part of the body, with regard to each of its powers; but with regard to sight, it is in the eye; and with regard to hearing, it is in the ear; and so forth." (Aquinas, ST I Q.76.Art.8.)

${ }^{52}$ See Rozemond, who cites Aquinas' Questiones de anima $\mathrm{X}$ ad 8: "Aquinas notes that since the intellect is not located in the body at all, the intellectual soul is in this sense not even whole in the whole body."(Rozemond, "Descartes, Mind-Body, and Holenmerism", p. 347.) I also thank Peter Distelzweig for discussion and clarification of this point.

${ }^{53}$ See Des Chene, Life's Form, pp. 172-173, for a discussion of the contrary positions (i) that all souls are divisible (asserted, for instance, by Pompanazzi) and (ii) that no souls are divisible (held by Marsilio Ficino); this latter view implies, Des Chene notes, that a new soul is produced when the cutting of a plant survives and grows.

${ }^{54}$ See Suarez, De anima 1.XIV.9, 10, discussed in Rozemond, "Descartes, Mind-Body, and Holenmerism”, p. 347.

${ }^{55}$ Cf. Aristotle, De anima I 5 411b19-31. At I 5 411b26, Aristotle writes, "It is found that plants, and among animals certain insects or annelida, live when divided, which implies that the soul in their segments is specifically, though not numerically, the same."(De anima, translated by R.D. Hicks; Cambridge: Cambridge University Press, 1907, p. 47). I thank Jim Lennox for the references.

${ }^{56}$ Suarez, Disputationes metaphysicae, XXX.VII.3, Opera omnia, vols. 25-26, translated and discussed by Rozemond in "Descartes, Mind-Body, and Holenmerism", p. 344-345.

${ }^{57}$ Suarez, Disputationes metaphysicae, XXX.VII.3, Opera omnia, vols. 25-26, translated and discussed by Rozemond in "Descartes, Mind-Body, and Holenmerism", p. 344-345.
} 
applying also to God. ${ }^{58}$ Finally, much as the rational soul is whole in every part of the body, this immanent God is whole in every part of creation. ${ }^{59}$ For Suarez, the extensions in which both finite spirits and the infinite spirit are present must be conceived in relation to bodies: "We cannot conceive the disposition and immensity of the divine substance except by means of a certain extension, which, of necessity, we explain by means of a relation to bodies. ${ }^{\circ 0}$ Conceived apart from real bodies, space is a potentiality for matter, Suarez continues, while also reaffirming holenmerism. ${ }^{61}$ Around the same time, however, some very different concepts of space and extension were being developed, as considered briefly in the next section.

\section{Dimensional and non-dimensional space, corporeal and incorporeal extension}

The ideas that extension implies corporeality and that the universe is finite were not universal to ancient thought. Leucippus and Democritus had allowed extension the independence that Aristotle would deny it. Extension for those fifth century atomists did not by itself imply corporeality; there existed an infinite, three-dimensional, incorporeal void space, conceived as the negation of matter, and material atoms moved in that space. In the Hellenistic period, Epicurus would defend the infinity of the universe by means of an argument that would see many iterations over the centuries, appearing in Locke's Essay among other places. ${ }^{62}$ Although one might suppose that the universe has a limit, it seems impossible to deny that upon reaching that alleged limit, it would be possible to reach a hand out beyond it. Yet if one supposed a new limit to be established by the tips of one's fingers, one must then allow that it would be possible to reach the hand out again; and since there is no limit to the number of times this process could be repeated, there is no limit to the universe. The Stoics would assert an infinite space beyond a finite cosmos, though the space became a plenum as they filled it with a thin but corporeal pneuma that could penetrate other matter.

\footnotetext{
${ }^{58}$ Rozemond, "Descartes, Mind-Body, and Holenmerism”, p. 346: "One argument Suarez cites relies on the principle that every agent must be joined to the patient on which the agent acts. The question is, Suarez writes, whether this principle really applies to God or only to finite agents. He concludes the principle applies to the "ratio agendi" as such, and is not dependent on issues of finitude (DM XXX.VII.12)."

${ }^{59}$ See Rozemond, "Descartes, Mind-Body, and Holenmerism", pp. 345-346: "The presence of the divine substance in creatures Suarez labels "whole in the whole and whole in the singular parts-tota in toto et tota in singulis partibus" This type of presence characterizes God but also angels and the rational soul. (DM XXX.VII.44). Indeed, Suarez argues that it pertains to God on the ground that it pertains to the rational soul, and, being a more perfect mode of presence, must also belong to God."

${ }^{60}$ Suarez, Disputationes Metaphysicae, vol. 2, p. 100, col. 1, par. 16, in Grant, Much Ado about Nothing, p. 155 (original Latin n.33, p. 355-356), his translation.

${ }^{61}$ The passage continues as follows: "And when we separate real bodies either from the thing itself, or in the mind, we necessarily perceive a certain space capable of being filled by certain bodies, [a space] in which the whole divine substance is present - the whole [divine substance] in the whole [space] and the whole [divine substance] in each of the particular parts of it [i.e., of the space]. And by this presence, we signify nothing other than the aforesaid disposition of the divine substance." Suarez, Disputationes Metaphysicae, vol. 2, p. 100, col. 1, par. 16, in Grant, Much Ado about Nothing, p. 155 (original Latin n.33, p. 355-356), his translation.

${ }^{62}$ Locke, E II.13.21
} 


\subsection{Space as an attribute of body and non-dimensional space beyond the cosmos}

Aristotle's earth-centered cosmos, by contrast, was finite, ending with the outermost celestial sphere. Through multiple arguments, he attempted to show that void space was impossible, whether intra-cosmic or extra-cosmic. For Aristotle, extension was an attribute of body, and that alone implied the impossibility of void space. Once extension is supposed to be an attribute of body, place must be as well, and Aristotle accordingly took a body's place to be the two-dimensional surface or boundary of the body or bodies surrounding it. $^{63}$

These features of Aristotle's understanding of extension and the cosmos were for the most part retained by his medieval followers, even under pressure to acknowledge some manner of space beyond the cosmos. Maintaining the impossibility of any space beyond the world implied a limitation on God's power, for it implied that although God might move the world by rotating it, he could not move it rectilinearly. The proposition that God could not so move the world, on pain of a vacuum being admitted, was among those targeted in the Condemnation of $1277 .{ }^{64}$ A response that would reaffirm God's omnipotence, in accordance with the 1277 edict, yet avoid allowing any actual infinite other than the deity, was to admit space beyond the cosmos, but to conceive it as the potentiality to receive body, and thus as a non-dimensional sort of space. Under the label 'imaginary space' and its cognates, other nondimensionalist notions of space had been introduced, yet in at least one of its usages, the term referred to a mind-dependent space - specifically, the mental fiction of something beyond the cosmos, a mistake entertained by people who cannot allow an end to extension. ${ }^{65}$ Any space intended to underwrite belief in God's omnipotence, by serving as a space into which he could move the world rectilinearly, had to be mind-independent, however. A non-dimensional space conceived as a genuine potentiality, rather than as a mistaken mental fiction, could underwrite divine omnipotence, while still remaining consistent with the Aristotelian view that real space was an attribute of body, namely, the extension of body.

The concept of non-dimensional space — space as potentiality for body—had considerable appeal then, but one should not suppose that concepts of dimensional space were therefore entirely absent or suppressed. On the contrary, among neo-Platonists, extension had been freed of its dependence upon matter; they transformed pneuma, which for the Stoics had been rare but corporeal, into something

\footnotetext{
${ }^{63}$ As John Henry notes, Aristotle does seem to allow in his Categories (6,5a, 5-14) that space and body are both dimensional, and yet are distinct, regions of the former occupied by the latter: "Space is a continuous quantity: for the parts of a solid occupy a certain space, and these have a common boundary; it follows that the parts of space also, which are occupied by the parts of the solid, have the same common boundary as the parts of the solid." See p. 517 of J. Henry, "Francesco Patrizi da Cherso's Concept of Space and its Later Influence", Annals of Science, 36 (1979), 549-575.

${ }^{64}$ On this point, see Grant, Much Ado about Nothing, p. 131 and 140-141.

${ }^{65}$ See Grant, ibid., pp. 117-121; in the seventeenth century, Otto von Guericke catalogued the meanings of the term 'imaginary space', and found them to include (i) a mental fiction; (ii) a possible but not actual space; (iii) something actual, namely, the immensity of God. This third meaning at least is rather elusive, due to many theologians' metaphorical use of spatial language in connection with God.
} 
extended but incorporeal, and John Philoponous (c. 490-570) had understood space as dimensional but incorporeal. ${ }^{66}$ Moreover, the notion of dimensional space was making inroads even among Aristotelians. One result of the 1277 edicts was the admission that God could create finite vacua. ${ }^{67}$ And as for the possibility of a dimensional, infinite void beyond the cosmos, some of Aristotle's followers, Thomas Aquinas included, ${ }^{68}$ inevitably yielded to the temptation to consider it, given the counter-intuitive nature of a limited universe beyond which there was simply nothing. Nevertheless, most of that speculation stopped short of asserting that such a space actually existed, and the notion that extension is an attribute of body had by no means been eliminated. John Buriden (1295-1358), for one, reaffirmed it: "The space [or distance] between me and you is nothing but the magnitude of the intervening air or of another natural body, if one should intervene." 69

\subsection{The readmission of actual, infinite, dimensional space}

Francesco Patrizi da Cherso (1529-1597) was the Renaissance figure whose work was most influential in securing the eventual acceptance of an actual, infinite, three-dimensional space. ${ }^{70}$ His contemporary Giordano Bruno (1548-1600) also broke with Aristotelian concepts of extension, place, and cosmos. Drawing upon Lucretius and through him, the fifth century atomists, Bruno asserted an actual, infinite, three-dimensional space, one that is continuous and indivisible; and though he took space to be filled with aether rather than truly void, it was nonetheless distinct from and prior to body, and thus able to persist in the absence of bodies. Yet it was Patrizi's work that would become influential, many of his concepts being carried forward by Pierre Gassendi (1592-1655) and Gassendi’s English expositor, Walter Charleton (1620-1707), eventually influencing More and then Newton.

In Patrizi's 1591 Nova de Universis Philosophia, he decisively distinguishes body and space. Far from being an attribute of body, extension or space is a condition of matter's existence. "What did the Supreme Maker create before all other things apart from Himself?", Patrizi asks. "Space itself", he then

\footnotetext{
${ }^{66}$ John Henry (1979), "Francesco Patrizi da Cherso's concept of space and its later influence”, p. 556. According to Philoponous, space is "pure dimensionality void of all corporeality"; John Philoponus, In Aristotelis physicorum libros quatttor priores commentaria (ed. H. Vitelli: 1888, Berlin), 567, in Henry, ibid.

${ }^{67}$ Grant, Much Ado about Nothing, p. 116.

${ }^{68}$ There is not full consensus about the claim that Aquinas denied a true void. Grant, for one, claims that he denied it (Much Ado, pp. 118; 145-146). Yet Funkenstein understands Aquinas as speculating about the possibility of an actual, extra-cosmic void (see Theology and the Scientific Imagination from the Middle Ages to the Seventeenth Century, p.61), and Centore suggests that Aquinas may have gone beyond speculation (see esp. pp. 355-358). We can at least agree that Aquinas does not abandon the Aristotelian conception, which is evident in passages such as the following: "But a thing is everywhere absolutely when it does not belong to it to be everywhere accidentally, that is, merely on some supposition; as a grain of millet would be everywhere, supposing that no other body existed."(I.Q.8.Art.4) Here Aquinas holds, with Aristotle, that the limit of the body is the limit of place; if no body other than the millet seed existed, the seed would be everywhere, since there is no place apart from existent bodies.

${ }^{69}$ John Buridan, in Grant, Much Ado about Nothing, p. 123.

${ }^{70}$ A detailed and insightful analysis of Patrizi's ideas and influence may be found in Henry ("A Cambridge Platonist's Materialism: Henry More and the Concept of Soul”); see also chapter 8 in Grant, Much Ado about Nothing. I have drawn upon both in my discussion here.
} 
answers, for nothing can exist without space; "when it is present all other things can be, when absent, all others are destroyed." ${ }^{71}$ In fact, Patrizi writes, in words echoed later by More and Newton, spatial location is a condition for the existence of anything whatsoever.

For all things, whether corporeal or incorporeal, if they are not somewhere, are nowhere; and if they are nowhere they do not even exist. If they do not exist they are nothing. If they are nothing, there will then be neither souls, nor natures, qualities, forms, or bodies. ${ }^{72}$

Patrizi's space has additional features that would reappear in More and Newton. It is immutable, indivisible, and immobile. ${ }^{73}$ Further, it is neither accident nor substance - or at least, it is not substance as defined in Aristotle's Categories because it is not an individual substance, composed of matter or form. Instead, it precedes all created things. Yet for reasons similar to those that would later lead Newton to conclude that space is more like substance than accident, Patrizi concludes that space is a unique kind of substance, if by substance we mean that upon which other things depend for their existence, but which does not depend upon anything for its own existence. ${ }^{74}$

Significantly, Patrizi's space it is not the non-dimensional space crafted after the 1277 edicts, a mere capacity for matter. It is instead an actual, infinite, dimensional space. ${ }^{75}$ Yet it has some odd features that would later be dropped. For one thing, the idea that extension uniquely characterizes body persists in Patrizi's language, even though he rejects the belief; he speaks of space as "a mean between" body and incorporeal substance, "an incorporeal body and a corporeal non-body". ${ }^{76}$ Another odd feature is that although Patrizi's space extends infinitely outward, ${ }^{77}$ it nonetheless has a center: "The center of Space...is at the midpoint of the infinite universum spacium." ${ }^{78}$ More specifically, the cosmos is spherical and geocentric, and contained by a finite space, which Patrizi calls locus. Extending infinitely outward from

\footnotetext{
${ }^{71}$ Patrizi, (trans. Brickman) 1943 [1591], p. 225.

${ }^{72}$ Patrizi, (trans. Brickman) 1943 [1591], p. 225.

73 "It always remains fixed per se and in itself, nor is it every or anywhere moved, nor does it change its essence or locus in any of its parts or in its entirety. Whatever is moved, is moved through this Space, but this Space does not move upon itself...For it would be moving through a part of itself, and the two parts of Space would be one within and on the other, and the locus of the part that moved would remain empty of Space, and thus Space would be empty of itself. It therefore does not move either as a whole or in its parts. It is therefore entirely unmoved and immovable." (Patrizi, trans. Brickman; 1943 [1591], p. 242)

${ }^{74}$ See Patrizi (trans. Brickman) 1943 [1591], p. 241.

${ }^{75}$ Patrizi defends an actually infinite space via the following argument (one that does not seem to target the medieval concept of non-dimensional space): "If it were said to be potential, it would necessarily follow that it is now finite, and that later it would become infinite, but still only potentially infinite. But if that is an absurdity, we conclude that it is actually infinite. But is it infinite with respect to lines, surfaces, or even depths? With respect to all of them, of course." (Patrizi (trans. Brickman) 1943 [1591], p. 237)

76 "What then is it [space], a body or an incorporeal substance? Neither, but a mean between the two. It is not a body, because it displays no resistance, nor is it ever an object of, or subject to, vision, touch, or any other sense. On the other hand, it is not incorporeal, being three-dimensional. It has length, breadth, and depth-not just one, two, or several of these dimensions, but all of them. Therefore it is an incorporeal body and a corporeal non-body."(Patrizi, trans. Brickman, p. 241).

77 "Space is not bounded by a body or by Space." (Patrizi, trans. Brickman, p. 237)

${ }^{78}$ Patrizi, p. 238. The idea of an infinite space having a center is not so odd if the center is understood as the locus of creation, from which space then extends, a point I thank Jim Lennox for mentioning. (The question of where God was before the creation might, however, plague those who take God to be immanent rather than transcendent.)
} 
the locus or containing space is a vacuum, which is not truly void but filled with incorporeal light. Thus space has two parts, a finite part and an infinite part (and because one of its parts is infinite, it does not constitute a whole ${ }^{79}$ ).

Again, however, Patrizi very decidedly distinguishes space and matter. The intrinsic nature of locus is no different from that of vacuum, and so if matter is removed from a locus, it becomes a vacuum. ${ }^{80}$ Or more dramatically: "If the world should be completely destroyed and become nothing...the Space in which the world is now contained, as locus, will remain entirely empty." ${ }^{81}$ Accordingly, it is not extension that peculiarly characterizes body but rather antitypia - resistance. ${ }^{82}$ Bodies resist one another, but space and bodies penetrate one another, posing no mutual resistance. ${ }^{83}$ Indeed, the movement of bodies, which are impenetrable to one another, provides evidence that space is distinct from body, for if we supposed there to be no empty spaces, we must believe either that bodies are unable to move, contrary to experience, or that they penetrate one another, which is contrary to the nature of bodies. ${ }^{84}$ (Descartes attempts to circumvent such arguments, while identifying matter with extension, by supposing that motion always proceeds in circuits.)

\subsection{Kinds of extension}

With the readmission of void space, we can distinguish three ways of understanding extension (leaving aside numerous variants ${ }^{85}$ ). One possibility is that seen among Aristotelians: there is a single kind of extension, and that one kind of extension is an attribute of matter. In consequence, that which is extended has parts outside parts, and is by its nature divisible and hence corruptible. In this case, there is no incorporeal extension such as void space, and an incorporeal entity cannot be extended except in the derivative sense of being present in matter, as noted earlier. This is the view of extension that Aquinas

\footnotetext{
${ }^{79}$ See Patrizi, p. 242

80 "When it is filled with a body, it is locus; without a body it is a vacuum. And on this account, this vacuum, like locus, must have the three common dimensions-length, width, and depth. And the vacuum itself is nothing else than three-dimensional Space.”(Patrizi, p. 231)

${ }^{81}$ Patrizi, p. 240

82 "For the property of a natural body, in so far as it is a natural body, is that antitypia mentioned above, and what is called anterisis. This is resistance (resistentia et renitentia)."(Patrizi, p. 231)

${ }^{83}$ Patrizi, p. 239

84 "Space, ever the same, ever fixed, must have length, width, and depth so as to release all bodies that leave it, and receive all bodies that enter it. Otherwise, we are faced with the interpenetration of bodies, which is impossible."(Patrizi, 230-231) A later passage contains a similar argument: "When water contracts, it must fill up the empty spaces interspersed within it, else you are faced with the interpenetration of bodies.... The air, likewise, yields to my body when I change my position in it. As it gives way it is either destroyed or else withdrawn into its other neighboring particles, and thus, either one part penetrate the other, or else it withdraws into the empty spaces interspersed within it. But we must not say that it was destroyed, without any previous transformation. Nor is the interpenetration of one part of the air with another admissible. Therefore, we must admit that it betook itself into the empty spaces of the nearby air." (Patrizi, 232-233)

${ }^{85}$ Although I have set out three main possibilities, other ideas about extension are of course possible. See, for instance, Funkenstein's discussion of Ockham's idea of extension: "Extension is, for Ockham, a connotative, relative notion by which a thing is recognized to have "parts outside parts" or parts separate from, yet together with, each other. Therefore a body can be thought of without this relation, so to say contracted to a point that is not "somewhere," and still be a body - such as the body of Christ."(Funkenstein, Theology and the Scientific Imagination from the Middle Ages to the Seventeenth Century, p. 60)
} 
for the most part accepts, though it may also be paired with the claim that spirits are transcendent, such as Descartes will attempt to maintain. With the readmission of void space, additional possibilities for understanding extension arise.

Another possibility, then, is that there is only one kind of extension, and that extension is incorporeal. If that incorporeal extension is identified with void space (and if void space is distinct from the deity) then the sense in which either a material or an immaterial being is extended would derive from that incorporeal extension, or at least, its quantities. This possibility may be constructed by extrapolating from what has been called the "creation story" ${ }^{" 86}$ in Isaac Newton's manuscript, De gravitatione et aequipondio fluidorum. ${ }^{87}$ After dismissing the notion that extension is an accident of body as a "puerile and jejune prejudice", ${ }^{88}$ Newton defines the things that we classify as bodies as "determined quantities of extension which omnipresent God endows with certain conditions", namely, mobility, impenetrability together with the associated tendency to be reflected according to certain laws, and the ability to excite sensations in perceivers. ${ }^{89}$ To be clear, these conditions are associated with certain quantities of extension, not parts of space itself, for space and its distinguishable parts are immobile, whereas bodies are mobile. ${ }^{90}$ A body's extension is the quantity of space in which its attributes exist. The extension of spirits could be understood along similar lines. If a created spirit consists in certain attributes, notably the passive power of receiving sensations and the active power of initiating movement, which coexist in some spatial distribution, then the spirit's extension is the quantity of that distribution.

A third possibility is that there are two kinds of extension, corporeal and incorporeal. Spiritual presence then could be understood in a number of different ways, depending upon what one takes incorporeal extension to be. If void space is the only kind of incorporeal extension, then the extension of a spirit would be derivative; a spirit would be extended if it were present in something extended, whether that be body, space, or both. (Here I am assuming, for the moment, that void space is not identified with God or considered an attribute of God.) Alternatively, one might take void space to be one sort of incorporeal extension while also claiming that immaterial spirits have an intrinsic quality of extension, one that is analogous to but distinct from (non-derivative) corporeal extension. This appears to be the view that More adopts in his later writings, when he concludes that spirits are extended in virtue of having

\footnotetext{
${ }^{86}$ See Stein, "Newton's Metaphysics", p. 275. Slowik refers to it as the "determined quantities of extension" hypothesis, or "DQE" hypothesis; see $\$ 3.1$ of "Newton's Neo-Platonic Ontology of Space".

${ }^{87}$ In "By y ${ }^{\mathrm{e}}$ Divine Arm: Substance and Method in De gravitatione", I develop the suggestion sketched here.

${ }^{88}$ Newton, De gravitatione et aequipondio fluidorum in Philosophical Writings, 27.

${ }^{89}$ Newton, De gravitatione et aequipondio fluidorum in Philosophical Writings, 28.

90 The point is evident in Newton's explanation of the conditions obtaining for those things that we classify as bodies: "therefore I did not say that they are the numerical parts of space which are absolutely immobile, but only definite quantities which may be transferred from space to space". See De gravitatione et aequipondio fluidorum in Newton: Philosophical Writings, 28. The original text reads as follows: "Quod si forent corpora, tum corpora definire possemus esse Extensionis quantitates determinatas quas Deus ubique praesens conditionibus quibusdam afficit: quales sunt (1) ut sint mobiles, et ideo non dixi esse spatij partes numericas quae sunt prorsus immobiles, sed tantum definitas quantitates quae de spatio in spatium transferri queant."(Newton, De gravitatione et aequipondio fluidorum, in Unpublished Scientific Papers, 106).
} 
quantitative "parts outside parts", but it is not the view found in his early writings, as the next section indicates.

\section{Henry More on space, spirits, and spiritual presence}

Throughout his life, More insisted that immaterial spirits are spatially extended in some manner, but despite that continuity, his ideas about the nature of space and about the manner of spiritual extension would undergo profound changes. Although he eventually accepts an actual, infinite, dimensional space, takes spirits to have quantitative parts, and repudiates holenmerism, these are not the ideas that characterize his early thought.

\subsection{Deluded, effascinated and befooled: The early More against the nullibists ${ }^{91}$}

Although More's ideas about immaterial spirits and spiritual presence were to undergo some dramatic changes, he consistently opposed the conception of spirits as transcendent, such that they have no spatial or temporal presence, location, or extension. ${ }^{92}$ Finding in Descartes' writings an exemplar of the view that spirits are transcendent, he declared, "Cartesius is the Prince of the Nullibists". ${ }^{93}$ More opposed this view in a 1648 letter to Descartes, pressing his anti-nullibist view that spirits have some sort of spatial extension.

It seems to me that God is an extended being, as are angels and, indeed, anything that subsists by itself, so that extension seems to be included within the same boundaries as the absolute essence of things, though it can nevertheless vary according to the variety of such essences. Now, for my part, I consider it to be evident that God is extended in His own manner from this: that He is certainly omnipresent, and He intimately occupies both the entire mundane machine and each individual particle thereof. For how could He impress motion onto matter, as He once did, and as you claim $\mathrm{He}$ still does even now, unless He closely touched the matter of the universe, or at least had once touched it? Which He certainly could never have done, if $\mathrm{He}$ was not present everywhere, and occupied each individual place. God is therefore extended or expanded in His own manner, and thus is an extended being. ${ }^{94}$

\footnotetext{
${ }^{91}$ The phrase is from More,p. 190 (ed. MacKinnon): "Wherefore when as the Nullibists come so near to the truth, it seems impossible they should, so all of a sudden, start from it, unless they were blinded with a superstitious admiration of Des Cartes, his Metaphysicks. and were deluded, effascinated and befooled with his jocular Subtilty and prestigious Abstractions there: For who in his right wits can acknowledge that a Spirit by its Essence may be present to Matter, and yet be no where, unless the Matter were nowhere also?"

${ }^{92}$ Indeed, as John Henry has pointed out, More's immaterial Spirit of Nature, which he took to actuate matter and thereby cause such phenomena as magnetism, cohesion, and the production of colors, which the mechanical philosophy could not explain, had to be extended in space. For More conceived of the Spirit of Nature in neo-Platonic terms, something that emanated outward, like an orb of light from a source. See Henry, $\$ 3$ of "Henry More", The Stanford Encyclopedia of Philosophy.

${ }^{93}$ Enchiridion Metaphysicum, Appendage: The True Notion of a Spirit; Sect. II, in Philosophical Writings of Henry More, ed. MacKinnon, p. 184. Despite such disagreements, More had admired Descartes and had disseminated his ideas in England; see Henry "Francesco Patrizi da Cherso's concept of space and its later influence", p. 175, including n.10.

${ }^{94}$ More to Descartes (December 11, 1648), More, Epistolae, 62; in Reid, "The Evolution of Henry More's Theory of Divine Absolute Space”, p. 93, his translation.
} 
As More sees things, spirits act, and this requires that they be present to the things upon which they act. A transcendent God would not be able to move matter, and so God must be present to matter in space, so that he can "touch" it. As More would argue much later (there echoing the medieval nominalists, against the Jesuits ${ }^{95}$ ), anyone who admits that a spirit's power is spatially located should acknowledge that the substance of the spirit itself is spatially located. ${ }^{96}$ At this stage of his thought, the manner in which More takes spirits to be spatially present or extended does not involve the quantitative parts outside parts that he would later decide are constitutive of extension; spirits are extended only in a derivative sense.

Despite a superficial appearance to the contrary, then, More's conception of spiritual presence at this stage resembles the one seen in Aquinas, and in several important respects. First, that to which the spirit is present does not yet include an actual, infinite, dimensional space. Second, at this stage he understands spiritual presence, or extension, as he sometimes calls it, in terms of the presence of the substance or essence, and that is not quantifiable, making spiritual extension derivative. The manner in which spirits are extended is quite different, at this stage, from the manner in which bodies are extended, though he does not express this as clearly as we might like. "One spirit goes through all this bulk", he writes in a 1647 poem, " $n o t$ by extension, but by a totall Self-reduplication". ${ }^{97}$ By contrasting extension with a spirit's presence, he seems to imply here that the spirit's "self-reduplication" is not a way of being extended, yet in his above-quoted letter to Descartes, written the next year, he indicates that a spirit's manner of being present is a kind of extension. God is "present everywhere, and occupied each individual place", and is "therefore extended or expanded in His own manner, and thus is an extended being". ${ }^{98}$ Again, his intent is to distinguish the intrinsic extension of bodies, which consists in parts outside parts, from the derivative manner in which spirits are extended, and we find a more direct contrast between the two in his next letter. Whereas corporeal extension involves "the external (but immediate) application and juxtaposition of parts", spiritual presence arises from "the ubiquitous repetition of the

\footnotetext{
${ }^{95}$ On this point see Des Chene: "To an Aristotelian versed in the machinery of distinctions devised by Ockham and Scotus it will naturally occur to wonder how the soul is distinguished from its powers (\$7). One answer, favored by Nominalists, is that the soul's powers, so-called, are only the soul itself, whose action is conditioned by the objects and organs through which it operates. The Jesuit authors, on the other hand, follow Thomas Aquinas in holding that between the soul and its powers there is a distinction, real in the sense that it does not depend on our conception." (Des Chene, Life's Form, p.7.)

${ }^{96}$ See Enchiridion Metaphysicum; Appendage: The True Notion of a Spirit; Sect. II, in Philosophical Writings of Henry More, ed. MacKinnon, p. 188. Interestingly, Descartes' position in the Principles of Philosophy commits him to that position, because in Book I $\$ 62$ (CSM, 214), he asserts that there is only a conceptual distinction, not a real one, between a substance and its attributes - which implies that God is only conceptually distinct from his omnipotence, and so must be located in rerum natura if his power is. Jasper Reid notes ("The Spatial Presence of Spirits among the Cartesians", p. 102) that when More presses Descartes on the issue during their correspondence, Descartes raises that very point-yet does so immediately after having claimed both (i) that God is omnipresent in virtue of his power, and (ii) that God's essence has no relation to place. In other words, having reaffirmed the claim that God's substance or essence is transcendent, Descartes allows that his power is spatially located, and then, as if it supported that position, he invokes a claim from his Principles that in fact undermines it, implying instead that God is immanent if his power is.

${ }^{97}$ More, Complete Poems, 62 (Psychathanasia, bk. 2, cant. 2, st. 33), in Reid, “The Evolution of Henry More's Theory of Divine Absolute Space", p. 91. I have emphasized the word 'not'; the other italics are original in More.

${ }^{98}$ More to Descartes (December 11, 1648), More, Epistolae, 62; in Reid, ibid., p. 93, his translation.
} 
total and integral essence". ${ }^{99}$ This essence is repeated or reduplicated in something possessing intrinsic extension, hence the derivative sense of a spirit's extension. And at this stage of his thought, the terms 'repetition' and 'self-reduplication' express the unity and non-quantitative nature of spirits. ${ }^{100}$ As indicated in the more recent letter to Descartes, he takes these self-reduplicating spirits to be unified wholes, indeed to be whole in every part; God's essence is "repeated and reiterated" within and without the world, God is "whole everywhere, and His whole essence is present in all places or spaces, and in all points of space", and "it does not follow that He has parts outside parts, or, consequently, that He is divisible." 101 The third point of resemblance to Aquinas and his ilk, then, is that More's early writings pair his anti-nullibist conception of spirits with the doctrine that spirits are whole in every part. (He dubs it 'holenmerism' only later, when repudiating it). The deity is whole in every part of creation, and the intellectual soul is whole in every part of the body, as we can infer from sensation: "What tells the hand or head the toes great grief, When it alone is pinch'd with galling shooes?"102

\subsection{A space which the mind can by no means disimagine, nor pluck out of her self ${ }^{103}$}

Two stages may be distinguished in More's ideas about space, stages that roughly recapitulate developments during the thirteenth century and the Renaissance. Initially, More denies the existence of an actual infinite void beyond the stars, first dismissing it as a "non-entity", ${ }^{104}$ and then allowing void space only in the non-dimensionalist sense crafted in the medieval period-a space which "is not the imagination of any real thing, but only the large and immense capacity of the potentiality of the Matter". ${ }^{105}$ Yet even during the period that he allowed only a non-dimensional void, he acknowledged

\footnotetext{
${ }^{99}$ More to Descartes, March 5, 1649, Epistolae, 76, in Reid, p. 93; his translation.

${ }^{100}$ In an impressive article deciphering the vagaries and obscurities of More's language, Jasper Reid has shown that the term 'self-reduplication' refers to something quite different in More's mature writings than it did in his early works. In early writings such as the poems of 1647 , he uses it to affirm the holenmerian doctrine that a spirit exists, in its entirety, at different places, but in his later works uses it in connection with the claim that spirits are extended in the sense of having "parts outside parts", albeit notional ones. See Reid, "The Evolution of Henry More's Theory of Divine Absolute Space”, p. 91.

${ }^{101}$ More to Descartes, March 5, 1649, Epistolae, 76-77, in Reid, p. 93; his translation.

${ }^{102}$ More, Psychathanasia, Book II, Canto II, Stanza 33, in Complete Poems, p. 62. Much later, when More repudiates holenmerism, he will cite this as the second of two reasons that the "holenmerians" accept the doctrine: "The other Reason is, That from hence it might be easily understood, how the Soul being in the whole Body, C, D, E, whatever happens to it in C, or B, it presently perceives it in A." (More, Enchiridion Metaphysicum, in MacKinnon, .p.198.) The first reason he attributes to those accepting the doctrine - but which does not describe the Scholastics, as noted elsewhere, and so may only describe More's earlier self - is that he takes it to ground the indivisibility of spirits.

${ }^{103}$ The sources of the phrases are (i) Divine Dialogues (1668), in which one character takes space to be "so imaginary that it cannot be disimagined by human understanding" (More 1668, 54, in Henry, SEP, §6); and (ii) Enchiridion Metaphysicum, in Philosophical Writings, (ed. MacKinnon), p. 215: "There is an Idea of infinite Extension drawn or taken in from no external Sense, but is natural and essential to the very Faculty of perceiving; which the Mind can by no means pluck out of her self, nor cast it away from her."

${ }^{104}$ From a 1651 letter from More to Anne Conway, in Reid, "The Evolution of Henry More's Theory of Divine Absolute Space", p. 83, who references Alan Gabbey, “Anne Conway et Henry More: Lettres sur Descartes (1650-1651)," Archives de Philosophie 40 (1977): 379-404; 388.

${ }^{105}$ More, An Antidote Against Atheism [Antidote], 200 (Appendix, ch. 7, §3), in A Collection.] in Reid, "The Evolution of Henry More's Theory of Divine Absolute Space", p. 83.
} 
that we are unable to free our minds of the idea of infinite space. The force of that idea eventually drove him to the second stage, in which he became convinced that infinite dimensional space, which is also immobile and indiscerpible, is real.

There is an Idea of infinite Extension drawn or taken in from no external Sense, but is natural and essential to the very Faculty of perceiving; which the Mind can by no means pluck out of her self...she will be constrained, whether she will or no, to acknowledge, that altho' the whole matter of the World were exterminated out of the Universe, there would notwithstanding remain a certain subtile and immaterial extension which has no agreement with the other Material one, in any thing, saving that it is extended, and being such that it neither falls under sense, nor is impenetrable, nor can be moved, nor discerped into parts; and that this Idea is not only possible but necessary, and such as we do not at our pleasure feign and invent, but do find it to be so innate and ingrafted in our Mind, that we cannot by any force or Artifice remove it thence, which is a most certain demonstration that all perception of Extension is not Imagination properly so called. ${ }^{106}$

An infinite extra-cosmic space that was real and dimensional constituted an additional place in which the omnipresent deity must be present, as Patrizi had acknowledged. ${ }^{107}$ More not only accepted this, he went further, construing infinite space as an attribute of God (even, at one point, as God himself ${ }^{108}$ ). Space is "not only something real...but even something divine", he asserted, attributing the following properties to both the deity and space: "One, simple, immobile, eternal...subsisting by itself, incorruptible". He also added something traditionally associated with God but harder to reconcile with space: "pure act". ${ }^{109}$ As More has the character Bathynous say at the end of his Divine Dialogues, "eternity is the proper and necessary eternal duration of God", and "that inmost extension or amplitude, which will necessarily remain after we have imagined all matter or what-ever else is removeable...out of the world, is to be look'd upon as the permanent expansion or amplitude of the radical essentiality of God." $" 110$

\footnotetext{
${ }^{106}$ Henry More, Enchiridion Metaphysicum, Appendage: The True Notion of a Spirit; Sect. II, in Philosophical Writings of Henry More, ed. MacKinnon, p. 215). Earlier, in Divine Dialogues, More had one of his characters acknowledge that space beyond the cosmos was difficult to "dis-imagine"; see Henry's discussion ("Patrizi's Concept of Space, p. 572; also p. 570, n.144).

107 "'If the universal deity is indivisible, as it is, it will be in indivisible space"; Patrizi, Nova philosophiae, 61b-c, in Henry, ), "Francesco Patrizi da Cherso's concept of space and its later influence", p. 570, his translation.

${ }^{108}$ In $\S 4-6$ of the 1655 Appendix to An Antidote against Atheism, More writes, "If after the removal of corporeal Matter out of the world, there will be still Space and distance, in which this very matter, while it was there, was also conceived to lye, and this distant Space cannot but be something, and yet not corporeal, because neither impenetrable nor tangible, it must of necessity be a substance Incorporeal, necessarily and eternally existent of it self: which the clearer Idea of a Being absolutely perfect will more fully and punctually inform us to be the Self-subsisting God."(More, in Koyre, Closed World, p. 137). There is some disagreement about whether this identification of space with the "self-subsisting God" was a one-off occurrence. According to Reid, it was: "After that isolated remark in the Appendix to An Antidote Against Atheism, More subsequently shied somewhat away from declaring space to be the very substance of God, but he was at least willing to identify it with one of His attributes." (Reid, p. 101) Henry, by contrast, holds that More implicitly made the identification elsewhere too: "This identification is implicit in the Divine dialogues (1668, London), vol. 1, 106, where space is considered to be 'a more general and confused apprehension of the divine amplitude,' and it is a space in which all things are 'necessarily apprehended to live and move and have their being' (p. 107)."(Henry, "Francesco Patrizi da Cherso's concept of space and its later influence", p. 571.)

${ }^{109}$ Enchiridium metaphysicum, cap. viii, 8, pp. 69 sq.; in Koyre, p. 148.

${ }^{110}$ Henry More, Divine Dialogues, Containing Disquisitions Concerning the Attributes and Providence of God, Glasgow: Printed by Robert Foulis, 1743; The Third Dialogue, Concerning the Providence of God, §XL; p. 448-449. Cuphophron responds that the point is obscure, but doubtless belongs to high metaphysics.
} 
Casting this actual, infinite, dimensional space as an attribute of God has conceptual implications for the manner in which God is extended, and then in turn for the doctrine of holenmerism. For if space is an incorporeal extension in which quantitative parts can be distinguished (though not actually divided from one another), and is also an attribute of God, it follows that a divine attribute has distinguishable, quantitative parts. As a matter of historical fact, however, More's change of heart about holenmerism was probably due, as Jasper Reid has argued, to theological concerns prompted by Hobbes' attack upon the doctrine. ${ }^{111}$

\subsection{Methinks spirits are only found in bottles: Hobbes against immaterial spirits and holenmerism ${ }^{112}$}

Against those of the "Schoole Divinity", Hobbes rejects the scholastic notion that there are "certaine Essences separated from Bodies, which they call Abstract Essences, and Substantiall Formes"113 in favor of a materialist position. As he explains in Leviathan, everything that exists is corporeal: "that which is not Body, is no part of the Universe", and that which is not body "is Nothing; and consequently no where". ${ }^{114}$ Since that which is not corporeal simply does not exist, those who truly mean 'not body' or 'incorporeal substance' when they say 'angel' or 'spirit', imply a contradiction. ${ }^{115}$ Spirits do exist, but they are actually corporeal, being called 'spirits' simply because they lack opacity. ${ }^{116}$ The doctrine that the spirit is whole in every part, Hobbes continues, is absurd.

The Essence of a Man, which (they say) is his Soule, they affirm it, to be All of it in his little Finger, and All of it in every other Part (how small soever) of his Body; and yet no more Soule in the Whole Body, than in any one of those Parts. Can any man think that God is served with such absurdities? And yet all this is necessary to believe, to those that will believe the Existence of an Incorporeall Soule, Separated from the Body. ${ }^{117}$

This attack depends upon the materialist conception of spirits that Hobbes has just defended. If the doctrine that the spirit is whole in every part is said to apply to spirits that are genuinely immaterial, then it in fact applies to nothing at all, since in his view there are no such things. If, however, the doctrine is said to apply to those spirits that do exist, namely, rare corporeal things, then it is incoherent. For as

\footnotetext{
${ }^{111}$ See Reid, "The Evolution of Henry More's Theory of Divine Absolute Space”, pp. 98-99.

${ }^{112}$ Ted McGuire tells me that Hobbes quips, "Methinks spirits are only found in bottles".

${ }^{113}$ Hobbes, Leviathan, Part IV, Of the Kingdome of Darkness, Chap. 46; p. 497; 1904 edition [1651].)

${ }^{114}$ Hobbes, Leviathan, Part IV, Of the Kingdome of Darkness, Chap. 46; p. 497-498; 1904 edition [1651].

${ }^{115}$ Hobbes, Leviathan, Part III, Of a Christian Common-Wealth; Chap. 34 p. 294-295; 1904 edition [1651]: "To men that understand the signification of these words, Substance, and Incorporeall; as Incorporeall is not taken for subtile body, but for not Body, they imply a contradiction: insomuch as to say, an Angel, or Spirit (is in that sense) an Incorporeall Substance, is to say in effect, there is no Angel nor Spirit at all."

${ }^{116}$ Hobbes, Leviathan, Part IV, Of the Kingdome of Darkness, Chap. 46; p. 497-498; 1904 edition [1651].

${ }^{117}$ Hobbes, Leviathan, Part IV, Of the Kingdome of Darkness, Chap. 46 p. 500; 1904 edition [1651]. Continuing his gibe, Hobbes asks how incorporeal spirits manage to "walk by night in...Church-yards", and wonders whether they will be said to "walke definitivè, not circumscriptivè, or spiritually, not temporally". Hobbes is, as More remarks, "very copious in [his] jearing" (More, The Immortality of the Soul, Book I, chp. X, §6, p. 94 in MacKinnon).
} 
Hobbes sees things, "Nothing can rightly be called a whole, that is not conceived to be compounded into parts, and that it may be divided into parts." ${ }^{118}$ In other words, the soul could be whole only if it has parts, but to have parts is to be actually divisible. Whereas the Scholastics recognized parts that are essential or conceptual, Hobbes recognizes only parts that are divisible from one another, which is to say the quantitative parts possessed by material bodies. By recognizing only quantitative parts, he implies a spirit to resemble something like blood. And if the spirit resembled blood, it would indeed be true that if it were wholly in the finger, there could be nothing remaining to be anywhere else in the body. Thus anyone granting Hobbes' premise about quantitative parts would indeed to be driven to conclude that the doctrine of holenmerism is absurd.

\subsection{The Scholastick riddle, a remedy far more intolerable than the disease: The later More against the holenmerians ${ }^{119}$}

More eventually grants Hobbes' premise that the only way of being extended is to have quantitative parts. More's purpose is of course very different from Hobbes' aim. Vigorously contesting the latter's claim that spirits are corporeal things whose matter is simply too subtle to perceive, More takes a spirit to be the contrary of matter. Having defined matter as a substance "destitute of all Perception, Life, and Motions", one that is "compounded of physical Monads, or at least of most minute Particles of Matter", divisible again into those parts, and impenetrable to other matter, ${ }^{120}$ he defines spirit "from the Law of Opposites". A spirit is "an Immaterial substance intrinsecally endued with Life and the faculty of Motion". ${ }^{121}$ From this law of opposites it also follows that since bodies are discerpible and impenetrable, spirits are indiscerpible and penetrable. ${ }^{122}$ Thus spirits have the capacity of penetrating matter and one another, which More refers to as a fourth dimension, "essential spissitude": "That besides those THREE Dimensions which belong to all extended things, a FOURTH also is to be admitted which belongs properly to SPIRITS....Altho' all Material things, consider'd in themselves, have three Dimensions only; yet there must be admitted in Nature a Fourth, which fitly enough, I think, may be called Essential

\footnotetext{
${ }^{118}$ Hobbes, De Corpore, Part II, Chp. VIII, pp. 97.

${ }^{119}$ In The Immortality of the Soul, 1659 (bk. 1, ch. 10, §8; discussed by J. Reid, p. 98), More terms the doctrine that the spirit is whole in every part "the Scholastick Riddle". The other phrase appears in Enchiridion Metaphysicum: The phrase is from More, "it is apparent the three Objections which we brought in the beginning do again recur here, and utterly overwhelm the first Reason of the Holenmerians: So that the Remedy is far more intolerable than the Disease."(p. 202 in Philosophical Writings, ed. MacKinnon)

${ }^{120}$ More, Enchiridion Metaphysicum, §XVII, p. 206-207 in MacKinnon.

${ }^{121}$ More, Enchiridion Metaphysicum, §XVIII, p. 207 in MacKinnon. Later in the same section, he explains that a spirit is one, true, and good.

${ }^{122}$ While it is clear in Enchiridion Metaphysicum that More takes spirits to be indiscerpible and penetrable, he indicated earlier, in The Immortality of the Soul, that the law of opposites is the ground for those characteristics: "I will define therefore a Spirit in generall thus, A substance penetrable and indiscerpible. The fitness of which Definition will be the better understood, if we divide Substance in general into these first kindes, viz. Body and Spirit, and then define Body to be A Substance impenetrable and discerpible. Whence the contrary kind to this is fitly defined, A Substance penetrable and indiscerpible." (More, The Immortality of the Soul, Book I, chapter III, §1, pp.65-66 in MacKinnon.)
} 
Spissitude." ${ }^{23}$ Yet despite his belief that spirits are immaterial, More now agrees with Hobbes that to be extended is to have quantitative parts, that is, the "parts outside parts" that could be mapped onto such parts of bodies.

More's newly found dimensionalist view of spirits is evident in the way that he implicitly construes spirits when repudiating holenmerism, and also in some of his general remarks, though some effort is required to discern his meaning. He may mean to suggest that extension consists in having parts outside parts in The Immortality of the Soul (1659), where he asserts the general principle that it is "of the very essence of whatsoever is to have Parts or Extension in some measure or other". ${ }^{24}$ That is the view that he accepts in Enchiridion Metaphysicum at least, despite some initial appearances to the contrary. Although in distinguishing immaterial or "metaphysical" extension from material extension, More sometimes slips into speaking as though he denied that the former involves parts outside parts, that appearance is eventually dispelled. ${ }^{125}$ It is not parts per se that More wants to deny to immaterial extension, but only discerpible parts: "Moreover...it is not at all prejudicial to our Cause, though we

${ }^{123}$ More, Enchiridion Metaphysicum, The True Notion of Spirit, §XXII, p. 213 in MacKinnon. See also The Immortality of the Soul, Book I, chapter II, Axiom IX, §11; p. 64 in MacKinnon: "Essential Spissitude: For so I will call this Mode or Property of a Substance, that is able to receive one part of it self into another. Which fourth Mode is as easy and familiar to my Understanding, as that of the Three dimensions to my Sense or Phansy. For I mean nothing else by Spissitude, but the redoubling or contracting of Substance into less space then it does sometimes occupy."

${ }^{124}$ More, The Immortality of the Soul, ed. Alexander Jacob, Dordrecht: Martinus Nijhoff Publishers, 1987; Preface, p. 7. The principle appears in an argument meant to show that the material particles comprising compound bodies are extended and yet divisible only intellectually, not actually. I do not find the statement's meaning unambiguous. For one thing, More does not tell us whether he means 'extension' as a synonym for 'parts', or instead means the phrase as a disjunction, such that the essence of being is either to have quantitative parts outside parts, or to be extended in some other, non-quantitative manner. Additionally, his main point in the passage is that an entity cannot exist if it is nowhere, as is evident from the next sentence, which reads, "For, to take away all Extension, is to reduce a thing onely to a Mathematical point, which is nothing else but pure Negation or Nonentity; and there being no medium betwixt Entity and Nonentity, it is plain that if a thing be at all, it must be extended." Reid, by contrast, interprets the passage as a straightforward claim that extension consists in having parts outside parts. See p. 98: "He decided that it was not only necessary to attribute extension in some sense to all substances. He now realized that such an attribution really did have to involve some sort of attribution of parts outside parts to them, albeit inseparable, notional parts in the case of immaterial substances: "it being the very essence of whatsoever is, to have Parts or Extension in some measure or other.”(More, Immortality, 39 (bk. 1, ch. 10, §8).]” See also Reid's remarks on pp. 96-97 and p. 102. Reid does emphasize on p. 93, in connection with Echiridion Metaphysicum, that in attributing parts outside parts to spirits, More was not saying that spirits are composed out such parts, but rather that such parts can be distinguished in the spirits.

${ }^{125}$ In distinguishing "immaterial extension" or "metaphysical extension" from material extension, More charges the nullibists with assuming that extension implies two qualities associated with matter, divisibility and impenetrability: "they presently imagine that it [extension] has partes extra partes, and is not Ens unum per se \& non per aliud, a Being one by it self, and not by vertue of another, but so framed from the juxtaposition of parts". Yet considered just in itself, More continues, extension "includes no such thing". (More, Enchiridion Metaphysicum, §XXIV of The True Notion of a Spirit, in MacKinnon, p. 216.) Does he mean to deny that immaterial extension involves partes extra partes? This passage really does not answer the question, for when More tells us that extension "includes no such thing", it is difficult to tell whether he means to oppose only the claim that extension implies being composed from a juxtaposition of parts (a claim that would in turn imply actual divisibility), or whether he also means to oppose the claim that every extended thing has parts outside parts. It is similarly difficult to extract a decisive answer from Section XXV. In that section, More aims to show "That every thing that is extended has not Parts Physically discerpible, though Logically or Intellectually divisible."(Ibid., p. 217) The nullibists are mistaken when they say "that all Extension inferreth Parts and all Parts Division". Does More mean to deny both conjuncts, or only one? If he means to deny the first as well as the second, then it would seem that he wants to say that immaterial extension does not involve the having of parts. And in fact his next remarks seem to assert just that: "The first is false, forasmuch as Ens unum per se, a Being, one of it self, or of its own immediate Nature, although extended, yet includes no Parts in its Idea, but is conceived according to its proper Essence, as a thing as simple as may be, and therefore compounded of no Parts." (Ibid., p. 217.) As noted next, however, More's subsequent remarks, as well as the setion's heading, indicate that he does not deny that spirits have parts, but only that they have discerpible parts. 
should grant that this Metaphysical Extension of spirits is also divisible, but Logically only, not Physically, that is to say, is not discerpible." ${ }^{126}$ Spirits have quantitative parts, then, but unlike the parts of bodies, they are not discerpible. This is, in fact, the point of the section's heading, which reads, "That every thing that is extended has not Parts Physically discerpible, though Logically or Intellectually divisible”.

More's conviction that immaterial extension consists in parts outside parts is also suggested by his claim that spirits possess a fourth dimension, essential spissitude. We may speak of a spirit's spissitude, he explains, when a spirit penetrates either another spirit or a body, but the concept "most properly appertains to those Spirits which can contract their Extension into a less Ubi", that is, into a smaller place. This amounts to a notion of substance density. ${ }^{127}$ There is a greater density of substance in a place just in case the place is occupied by: a spirit as well as a body; more than one spirit; or a single spirit that previously occupied a larger place. In connection with this last case, he elaborates as follows: "wherever there...[is] more of the same Essence in the same Ubi than is adequate to the Amplitude thereof, there this Fourth Dimension is to be acknowledged, which we call Essential Spissitude." "28 Here we have something very different from Aquinas, who would not agree that there can be "more of the same Essence" in a given place. For Aquinas, the essence of God concerns his causal power and relation to all that exists, and that causal power and relation to creation is not a quantifiable thing that could expand or contract, such that there would be more or less of it in a given place. As for the rational soul, its essence concerns the internal structuring it provides for the embodied person, an in-forming which is not quantifiable; whereas there is less of a body to in-form after an amputation, the in-forming essence cannot be spoken of in such terms. For More, however, there can be more, less, or an "adequate" amount of essence relative to a place. Although the spirit's parts are "notional", in that they cannot be actually divided, the fact that they can be more or less marks them as quantitative parts.

More now repudiates holenmerism. As we saw in the section on Hobbes, that doctrine would be incoherent if predicated of spirits said to have quantitative parts. Significantly, when More repudiates the

\footnotetext{
${ }^{126}$ More, Enchiridion Metaphysicum, $§ X X V$ of The True Notion of a Spirit, in MacKinnon, p. 217. The preceding section similarly suggested that there is "another Extension, namely, an Immaterial one", which is penetrable and yet cannot be torn into parts by anything, which is to say that no thing, whether material or immaterial, can "disjoin any thing of its Essence any where."(§XXIV, pp. 216-217) Why exactly is it impossible to separate any of its essence? While here More says only that such a spirit is "One of its own Nature, and held together into one by virtue of some other, either Quality or Substance"(p.217), the course of his reasoning suggests that from the failure of extension to imply divisibility conceptually, we get the possibility of an extended being that is not actually discerpible, and from our other reasons to believe in spirits, we can take that possibility to be realized, as the spirits we have conceived on other grounds.

${ }^{127}$ An interesting counterpoint to More's suggestion that immaterial spirits may be more or less dense is the concept of indeterminate dimension, developed in connection with body. On that concept in the thinking of Aegidius and of Averroes, see see Edith Sylla, 'Godfrey of Fontaine on Motion', in Studi sul XIV secolo in memoria di Anneliese Maier, ed. Alfonso Maierù and Agostino Paravicini Bagliani; Roma: Edizioni di Storia e Letteratura,1981; 110-115. On related issues, see Anneliese Maier, 'Das Problem der quantitas materiae', in Die Vorläufer Galileis im 14. Jahrhundert (Roma: Edizioni di Storia e Letteratura, 1966.)

${ }^{128}$ More, Enchiridion Metaphysicum, The True Notion of Spirit, §XXII, p. 213 in MacKinnon.
} 
doctrine, he implicitly construes spirits in quantitative terms. Referring to an illustration of a spherical body whose periphery is denoted by $\mathrm{D}, \mathrm{C}$, and $\mathrm{E}$, and which contains internal points $\mathrm{A}$ and $\mathrm{B}$, he writes:

When the Holenmerians add farther That the whole Soul is in every part or physical point of the Body... such as may justly be deemed next door to an open repugnancy and contradiction; for when they say the whole Soul is in the whole Body D, C, E, if they understand the Essence of the Soul to be commensurate, and as it were equal to the Body D, C, E, and yet at the same time, the Soul to be contained within the point A or B, it is manifest that they make one and the same thing many Thousand times greater or less than it self at the same time which is impossible. But If they will affirm that the essential Amplitude of the Soul is no bigger than what is contained within the physical Point A or B, but that the essential Presence of the Soul is diffused through the whole Body D, C, E, the thing will succeed not a jot the better, for while they plainly profess that the whole Soul is in the Point A, it is manifest that there remains nothing of the Soul which may be in the Point $\mathrm{B}$, which is distant from A, for it is as if one should say, that there is nothing of the Soul which is not included within A; and yet in the same moment of time, that not only something of the Soul, (which perhaps might be a more gentle repugnancy) but that the whole is in B, as if the whole Soul were totally and entirely out of it self; which surely is impossible in any singular or individual thing. ${ }^{129}$

Edward Grant describes these as "powerful arguments", which press the holenmerian to explain how a whole could be divided into wholes, how one and the same thing could be simultaneously thousands of times greater or less than itself, and how God, if reduced to a single point, could be in every other point of space. $^{130}$

Yet are More's arguments so powerful? According to the dilemma that he attempts to foist upon the holenmerians, either they must say that the soul's essence is commensurate with the entire body, while also saying that it is contained within some point of the body; or they must say that the soul's amplitude is no bigger than a point within the body, while still saying that it is diffused through the entire body. But both options presume exactly what Aquinas denied, namely, that essence is, like blood, the sort of thing that is quantifiable and has quantifiable parts. According to Aquinas, however, "totality of essence is not commensurate to totality of place", and immaterial spirits do not have quantity in any manner whatsoever, "except in reference to the perfect idea of their essence". ${ }^{131}$ Even the body that More uses to illustrate his claims is misleading, suggesting as it does a lifeless planet or snowball. The sort of body that a rational soul informs is a living one, whose possession of reason, self-motion, ten fingers and two legs are all produced by a single essence, performing its in-forming work in brain, limbs, and every other part.

\footnotetext{
${ }^{129}$ More, Enchiridion Metaphysicum, The True Notion of Spirit, §XII, pp. 199-200 in MacKinnon.

${ }^{130}$ See Grant, Much Ado about Nothing, p. 253. McGuire and Slowik also consider More's arguments compelling: "Probably in the wake of Hobbes's attack on the absurdity of holenmerism...More came to see that the presence of incorporeal substances in space needed to be defended by better and more positive arguments....He faces this task squarely in his Divine Dialogues (1668). The claim that the soul, for example, can be at once wholly in the human toe and wholly in the head, means that if it is wholly "in the Toe, there is nothing left to be in the head" $(1743,72)$. From this follows the absurd consequence that God's amplitude is reduced to a minute point, resulting in the instantiation of Divine omnipresence in multiple totalities. This, of course, contravenes the essential unity that incorporeal substances must possess." (McGuire andSlowik, $\$ 2$ of "Newton's Ontology of Omnipresence and Infinite Space".)

${ }^{131}$ Aquinas, Summa Theologiae, Q.8.Art.2, reply to obj.3.
} 
Completing his misrepresentation of the doctrine that the spirit is whole in every part, More now asserts that those accepting the doctrine did so as a means of grounding the indivisibility of spirits. One of the reasons they embrace the doctrine, More asserts, is "That from hence it might be easily understood, how the Soul being in the whole Body, C, D, E, whatever happens to it in C, or B, it presently perceives it in $\mathrm{A} "{ }^{132}$ This is the reason he invoked long ago when, embracing the doctrine, he suggested that the soul's whole presence in every part explains what tells the head "the toes great grief, when... pinch'd with galling shooes". ${ }^{133}$ The other reason, More asserts, is that the doctrine is meant to ground indivisibility:

Whereas they grant that the whole Soul does pervade and possess the whole Body, they thought it would thence follow, that the Soul would be divisible, unless they should correct again this Assertion of theirs, by saying, that it was yet so in the whole Body; that it was totally in the mean time in every part thereof; for thus they thought themselves sure, that the Soul could not thence be argued in any sort divisible, or corporeal, but still remaining purely Spiritual. ${ }^{134}$

Here too, the holenmerians that More is describing seem to be his earlier self (reduplicated) — not Aquinas and others who had asserted the doctrine over previous centuries. More supposes that the claim that the soul pervades the whole body implies divisibility, and that the doctrine that the spirit is whole in every part constitutes an attempt to block that implication by simply stipulating spirits to be indivisible. ${ }^{135}$ What More fails to recognize is that for Scholastics such as Aquinas, there is no need to stipulate that spirits are indivisibles, since the indivisibility of spirits is already ensured by their lack of quantitative parts. Aquinas' claim that the spirit is whole in every part is not a means of grounding indivisibility. It is an implication of the manner of spiritual presence-presence by essence and power. Once again, one cannot say of the Thomist rational soul that there is a certain part that causes its bearer to have reason, and that that part can be mapped onto one region of the body, while another part causes its bearer to be bipedal, and can be mapped onto some other region. Rather, the essence that does both of those things does so by in-forming every part of the body, not part by part, but as a single thing. Similarly for God, one cannot say that his causal power has parts that can be mapped onto regions of the world or of space, such that one part of his power causes and sustains the planets, and can be mapped onto the regions of space that they occupy, while another part causes terrestrial life and can be mapped onto the surface of the earth. Rather, his one omnipotence causes all of those things. For those who understood spirits along the lines that Aquinas did, indivisibility and the presence of the entire spirit in each part of that which it occupies follow as consequences of the concept of spirit.

\footnotetext{
${ }^{132}$ More, Enchiridion Metaphysicum, The True Notion of Spirit, §XI, pp. 198 in MacKinnon.

${ }^{133}$ More, Psychathanasia, Book II, Canto II, Stanza 33, in Complete Poems, p. 62.

${ }^{134}$ More, Enchiridion Metaphysicum, The True Notion of Spirit, §XI, pp. 198 in MacKinnon.

${ }^{135}$ In another section, he weakens his charge, writing that the doctrine of holenmerism is either "superfluous or ineffectual". Since the doctrine as conceived by most of its proponents was not needed to block divisibility, to describe it as ineffectual would be misleading. More is closer to the mark, then, with the possibility that holenmerism is superfluous, yet that too is misleading, since the doctrine does express an important aspect of the spiritual presence implied by a certain concept of spirit.
} 
The doctrine of holenmerism, then, does not aim to guarantee a spirit's indivisibility, since indivisibility is already guaranteed by the non-dimensionalist concept of spirit with which it is associated. Further, the doctrine becomes incoherent only if predicated of spirits understood as having quantitative parts, either because they are material, as Hobbes said, or because an incorporeal kind of quantitative part is introduced and attributed to them, as in More's unconventional view. The entire attack upon holenmerism is therefore misguided. ${ }^{136}$ The doctrine is not inherently incoherent, then, and for anyone denying that spirits have quantitative parts, there is no prima facie reason to reject holenmerism.

\subsection{Difficulties in More's dimensionalist concept of spirit}

Since it turns out that there is no prima facie reason to avoid holenmerism, there is no obvious advantage to gain by adopting More's dimensionalist concept of spirit. Might there be any disadvantages? Unsurprisingly, his concept raises some difficulties. If he is to avoid holenmerism successfully, he must have some mind-independent basis for individuating the spirit's quantitative parts. He has said that the parts are "logically or intellectually divisible". This cannot refer to the logical distinctions that Aquinas or Suarez might draw among the logical or essential parts of an essence, for those are not quantitative parts. For the parts of More's spirits to qualify as parts outside parts, it must be possible, at least in principle, to correlate them with distinguishable parts of space or divisible parts of bodies. And if the parts are to be real, so that he can succeed in avoiding holenmerism, there must be some objective means of making that correlation. Yet if we consider the possible bases for the claim that a spirit has real, quantitative parts, dangers to other aspects of More's view emerge; he may lose the claim that spirits are simple, or even be driven toward materialism.

Since More has defined a spirit as an immaterial substance possessing intrinsic powers of life and motion, we might expect the spirit's particular powers of life and motion to determine its quantitative parts. The passive power of receiving images, for instance, might reasonably be said to correspond to a quantitative part of the spirit that penetrates and is co-extensive with the eye. Yet what of the active power to move the eyeball — does this belong to that same part of the spirit, or to a different part? If it is said to belong to the same part, what would be the ground for assigning the passive and active powers to the same quantitative part of the spirit? If it is said to belong to a different part, would that be a distinct quantitative part that is also co-extensive with the eyeball, or should that active power be understood as an instance of the will or power to move any part of the body, and which is thus co-extensive with the body

\footnotetext{
136 The proper target for More is the non-dimensionalist concept of spirit, and for Hobbes it is the notion of immaterial spirit generally. Geoff Gorham raises the question of whether one might defend More (and perhaps Hobbes too) by pointing out that Aquinas' notion of spiritual extension depends upon an ontology that More rejects, one in which substantial forms and essences qualify as a kind of parts. My point here may be seen as a response to that question. Instead of attacking the ontology directly, More (like Hobbes) attacks holenmerism directly, but misconstrues that doctrine because he fails to see that it is simply a consequence of the ontology. The better strategy, then, would be to attack the ontology directly.
} 
as a whole? At a minimum, it may be difficult for More to retain the claim that spirits are simple. Another difficulty is that the view potentially leads to materialism. ${ }^{137}$ For suppose that the spirit's quantitative parts are to be individuated according to the powers associated with the body's quantitative parts. While More wants to say that the quantitative parts possessing those powers belong to a spirit, once the parts become quantitative, parsimony suggests that they might actually belong to the material body instead. ${ }^{138}$ Yet if he tries to avoid that by supposing that the spirit's quantitative parts do not correspond to bodily parts, according to their powers, then the spirit's parts begin to look arbitrary and hence mind-dependent, which leads back to holenmerism.

\section{Conclusion}

As we have seen, the doctrine of holenmerism was historically associated with a certain nondimensionalist concept, one which takes spirits to lack the quantitative parts that characterize matter and instead to be present in matter and space by their essence and powers. It is that concept, rather than the doctrine of holenmerism, that ensures the spirit's indivisibility, and the claim that the spirit is whole in every part simply follows as a consequence. Failing to realize these points, those who charged the doctrine with incoherence implicitly applied it to their own dimensionalist concepts of spirits, and then reached the related conclusions that the doctrine was intended to block divisibility and that it was incoherent. Both conclusions are erroneous, as we have seen.

In closing, I will briefly suggest some applications to Newton's thought. Since holenmerism is not inherently incoherent, there is no reason to suppose that a charitable reading of Newton takes him to deny it. Moreover, support for the doctrine is suggested by a surface reading of certain passages, including his remark in De gravitatione that it is no more contradictory to say that a mind "can be diffused through space without any concept of its parts" than to understand a moment of duration as being diffused through space without parts. ${ }^{139}$ The surface reading, I think, is the one we should accept. ${ }^{140}$ A key realization is

\footnotetext{
${ }^{137}$ John Henry observes that despite his intentions to the contrary, More's concept of spirits opens the door to materialism: Although he "was always concerned to avoid the attribution of activity to matter and the attribution of materiality to spirit....we can see More being ineluctably drawn towards a materialist concept of spirit. The rot sets in as a result of More's Neoplatonist conviction that real existence is nonsensical except for extended entities."(Henry, "Francesco Patrizi da Cherso's concept of space and its later influence", p. 176. See also pp. 173-174, where Henry references D.P. Walker's observation that More tended to identify the soul with the subtle but material 'animal spirits'.)

${ }^{138}$ Ed Slowik notes that opponents of holenmerism might claim the following advantage: "A spatial view of the mind more closely follows what we know today about mental functions. My language abilities are on the left side above the ear, and motor skills in the back, etc.; hence a part-like or extended conception of the mind/soul might actually be a successful prediction made by the anti-holenmerists" (Slowik, personal correspondence, July 3, 2011). Yet it is not incidental that such contemporary theorists avoid the identification implied by the locution 'mind/soul', having eliminated immaterial spirits from their ontologies; and the immaterial soul is what an anti-holenmerist such as More is very determined to preserve.

${ }^{139}$ Newton, De gravitatione in Newton: Philosophical Writings, p. 26.

${ }^{140}$ An opposing view is taken by McGuire and Slowik "Newton's Ontology of Omnipresence and Infinite Space", and by Slowik, "Newton’s Neo-Platonic Ontology of Space”, §4.2.
} 
that holenmerism is not an independent doctrine, something to be invoked as a means of guaranteeing indivisibility, but is rather a consequence of a certain non-dimensionalist concept of spirit. Once an immanentist concept of spirit is adopted - and as is well known, Newton takes spirits to exist in rerum natura - then spirit must be conceived either as dimensional, having the parts outside parts that could in principle be correlated with the divisible parts of bodies, or as non-dimensional, lacking parts outside parts and being spatially extended in a derivative sense. And because holenmerism follows from a certain non-dimensionalist concept, then once an immanentist position is adopted, then either the spirit is whole in every part or it is not. If it is not, then it is part in every part. There is no tertium quid to be carved out by such means as pointing to space's indiscerpibility and on that ground denying that space has parts for a spirit to be in; for the parts at issue are not only the indiscerpible parts of space, but also the discerpible parts of bodies. This is so first because the question about holenmerism must be considered with respect to the relation betweeen finite minds and bodies; and second because in considering it with respect to the deity, one must consider the deity's relation to the actual world, which includes not only indivisible space but also divisible bodies. A further question, of course, is whether Newton holds a concept of spirit that implies holenmerism, or whether his ontology could even accommodate such a concept; for the nondimensionalist concept of spirit that implied holenmerism received its fullest development within a scholastic ontology. Building upon the ideas sketched in section 3.3, I suggest elsewhere that it can. ${ }^{141}$

\section{Acknowledgements}

This paper was written during a postdoctoral fellowship at the University of Pittsburgh's Center for Philosophy of Science, whose funding and support I gratefully acknowledge. For their generosity in discussing my ideas when in nebulous form, I thank the members of the Center's reading group. For an illuminating discussion of scholastic ideas about divisibility, I thank Peter Distelzweig, and for comments on an earlier draft, I thank Benny Goldberg, Geoff Gorham, Jim Lennox, Alan Nelson, Nicholas Rescher, and Ed Slowik, shortcomings being my own. I dedicate this paper to the spirit of Elaine Kochiras Tamvakis.

\footnotetext{
${ }^{141}$ I elaborate upon the ideas sketched here in "Newton and the Doctrine of Holenmerism". A less tractable difficulty is that of maintaining a distinction between the view that spirits are transcendent, their powers alone reaching into the world, and the view that spirits are immanent and constituted by powers existing in the world.
} 


\section{References}

Aquinas, Thomas, Summa Theologiae, Translated by Fathers of the English Dominican Province. New York: Benziger Bros. 1947.

Aristotle. De anima, translated by R.D. Hicks; Cambridge: Cambridge University Press, 1907.

Dempsey, Liam, "Written in the flesh: Isaac Newton on the mind-body relation", Studies in History and Philosophy of Science, Vol. 37, No.3 (2006), pp. 420-441.

Descartes, Rene, The Philosophical Writings of Descartes, trans. John Cottingham, Robert Stoothoff, and Dugald Murdoch; Vol. I-II, Cambridge: Cambridge University Press, 1985, abbreviated CSM.

Des Chene, Dennis. Life's Form: Late Aristotelian Conceptions of the Soul, Ithaca: Cornell University Press, 2000.

Funkenstein, Amos. Theology and the Scientific Imagination from the Middle Ages to the Seventeenth Century. Princeton University Press, 1986.

Grant, Edward. Much Ado about Nothing: Theories of Space and Vacuum from the Middle Ages to the Scientific Revolution. New York: Cambridge University Press, 1981.

Henry, John, "Henry More", The Stanford Encyclopedia of Philosophy (Fall 2007 Edition), Edward N. Zalta (ed.), URL $=<$ http://plato.stanford.edu/archives/fall2007/entries/henry- more/>. Accessed January $15,2011$.

Henry, John: “A Cambridge Platonist's Materialism: Henry More and the Concept of Soul”, Journal of the Warburg and Courtauld Institutes, Vol. 49 (1986), pp. 172-195.

Henry, John, "Francesco Patrizi da Cherso's Concept of Space and its Later Influence”, Annals of Science, 36 (1979), 549-575).

Hobbes, Thomas, De Corpore, ed. Sir William Molesworth; London: John Bohn, Henrietta St., Covent Garden, 1839 [1656] (C. Richards, printer; St. Martin's Lane).

Hobbes, Thomas, Leviathan, 1904 edition [1651], ed. A.R. Waller, Cambridge: at the University Press.

Kochiras, Hylarie. "Newton and the Doctrine of Holenmerism" (manuscript, n.d.).

Kochiras, Hylarie. "By y ${ }^{\mathrm{e}}$ Divine Arm: Substance and Method in De gravitatione" (manuscript, n.d.).

Koyré, Alexander, From the Closed World to the Infinite Universe. Baltimore: The Johns Hopkins Press, 1957.

Locke, John, An Essay Concerning Human Understanding, ed. Peter H. Nidditch, New York: Oxford University Press, 1975.

Maier, Anneliese. Studien zu Naturphilosophy der Spätscholastic, I: Die Vorläufer Galileis im 14. Jahrhundert, pp. 26-52 ("Das Problem der quantitas materiae"). 
McGuire, J.E. and Slowik, Edward, "Newton's Ontology of Omnipresence and Infinite Space”, Oxford Studies in Early Modern Philosophy (forthcoming).

McGuire, J.E.. "Newton on Place, Time, and God: An Unpublished Source", British Journal of the History of Science, Vol.11, No. 2 (1978), pp. 114-129.

More, Henry, The Complete Poems of Dr. Henry More (1614-1687), collected and edited by The Rev. Alexander Balloch Grosart, St. George's Blackburn, Lancashire. Edinburgh University Press. Printed for private circulation, 1878 .

More, Henry. Philosophical Writings of Henry More, ed. F.I. MacKinnon. New York: Oxford University Press, 1925.

Newton, Isaac: Newton: Philosophical Writings, ed. Andrew Janiak, Cambridge: Cambridge University Press, 2004.

Newton, Isaac, Unpublished Scientific Papers of Isaac Newton, ed. A.R. Hall and Marie Boas Hall, Cambridge: Cambridge University Press, 1962.

Patrizi, Francesco, and Brickman, Benjamin (trans. and commentary): "On Physical Space” (De Spacio Physico), in Journal of the History of Ideas, Vol. 4, No. 2 (April, 1943): 224-245.

Power, J.E.. "More and Newton on Absolute Space", Journal of the History of Ideas, Vol. 31, No. 2 (1970), pp. 289-296.

Reid, Jasper. "The Evolution of Henry More's Theory of Divine Absolute Space”, Journal of the History of Philosophy, 45 (2007), pp. 79-102.

Reid, Jasper, "The Spatial Presence of Spirits among the Cartesians" Journal of the History of Philosophy, Volume 46, Number 1, January 2008, pp. 91-117.

Rozemond, Marleen. “Descartes, Mind-Body Union, and Holenmerism”, Philosophical Topics, Vol. 31, Nos. $1 \&$ 2, Spring and Fall, 2003, pp. 343-367.

Slowik, Edward. “Newton’s Neo-Platonic Ontology of Space”, Foundations of Science (forthcoming).

Slowik, Edward. Newton's Metaphysics of Space: A “Tertium Quid” betwixt Substantivalism and Relationism, or Merely a "God of the (Rational Mechanical) Gaps"? Perspectives on Science, Volume 17, Number 4, Winter 2009, pp. 429-456.

Stein, Howard, "Newton's Metaphysics", in Cambridge Companion to Newton, I. Bernard Cohen and George E. Smith (eds.), Cambridge University Press, 2002, pp. 256-307.

Sylla, Edith. "Godfrey of Fontaine on Motion", in Studi sul XIV secolo in memoria di Anneliese Maier, ed. Alfonso Maierù and Agostino Paravicini Bagliani; Roma: Edizioni di Storia e Letteratura, 1981. 